\title{
STYLES OF HYDROTHERMAL ALTERATION AND GOLD MINERALIZATION ASSOCIATED WITH THE NOVA LIMA GROUP OF THE QUADRILÁTERO FERRÍFERO: PART II, THE ARCHEAN MESOTHERMAL GOLD-BEARING HYDROTHERMAL SYSTEM
}

\author{
LYDIA MARIA LOBATO*\& FREDERICO WALLACE REIS VIEIRA**
}

\begin{abstract}
RESUMO ESTILOS DE ALTERAÇÃO HIDROTERMAL E MINERALIZAÇÕES AURÍFERAS ASSOCIADAS COM O GRUPO NOVA LIMA DO QUARILATERO FERRIFERO: PARTE II, O SISTEMA HIDROTERMAL AURIFERO MESOTERMAL AROUEANO Depósitos mesotermais, estruturalmente controlados do tipo lode-gold ocorrem em terrenos metamórficos e constituem um grupo específico de sistemas epigenéticos de met als preciosos. Muitos depósitos mesotermais de ouro no Quadrilátero Ferrífero (QF), Minas Gerais, Brasil, são englobados no grupo pertencente aos greenstone belts do Arqueano e encaixados em rochas típicas de associações metamórficas das fácies xisto-verde e sub-anfibolito. Em geral, a alteração hidrotermal dos mesmos caracteriza uma zona central de carbonates de ferro, normalmente com albita e micas, gradando para calcita e clorita. Venulações quartzosas e sulfetação também desenvolvem-se, com ouro incluído principalmente nos sulfetos. Os fluidos mineralizantes eram ricos em $\mathrm{CO} 2-\mathrm{H} 2 \mathrm{O}$, de salinidade relativamente baixa, de pH próximo do neutro a algo alcalino e de caráter geralmente redutor. No caso do QF, variações na fração molar Xco2 e nas atividades de $\mathrm{K}^{+} / \mathrm{H}^{+}$e $\mathrm{Na}^{+} / \mathrm{H}^{+}$controlaram as paragêneses de alteração das rochas metamáficas e meta-ultramáficas. Clorita domina a alteração incipiente e carbonates a avançada, sugerindo que um fluido dominado por $\mathrm{H}_{2} \mathrm{O}$ evoluiu de fluido original com valores maiores da razão $\mathrm{CO} 2: \mathrm{H}_{2} \mathrm{O}$, típico dos estágios mais avançados da alteração hidrotermal. Mudanças nos parâmetros ais and Xco2 controlaram a alteração carbonática e a sulfetação de formação ferrífera bandada (BIF), rocha pobre em Al. A capacidade dos minerais da fi/Fem tamponar a/32 do fluido infiltrante determinou a 1) ass (e Xco 2 ) do fluido em evolução, e assim 2 ) associação de sulfetos no espaço físico, no espaço químico e no tempo geológico. Variações na $\mathrm{a}_{\mathrm{s}}$ e $\mathrm{P}_{\text {fluido }}$ também podem ser deduzidas pela alteração da $B I F$, à qual associa-se a deposição de ouro. Zonas de cisalhamento são ocupadas principalmente por pirrotita, enquanto pirita + arsenopirita ocorrem substituindo o bandamento da $B I F$. Os estágios de alteração incipiente (tamponado) e mais avançados (não tamponados) refletem a gradual evolução composicional de um fluido original externo, relativamente uniforme, através da interação com encaixantes, assim refletindo variações na razão fluido versus rocha. A alteração hidrotermal e precipitação de ouro associada foram praticamente isotérmicas, estando de acordo com cálculos de temperatura e pressão para diversos depósitos em outras partes do mundo. As pequenas variações em $f \mathrm{O}_{2}$, pH e ais, sugeridas para os depósitos no QF, tiveram provavelmente um importante papel na deposição do ouro.
\end{abstract}

Palavras-chave: ouro, Quadrilátero Ferrífero, condições na alteração hidrotermal

ABSTRACT Structurally hosted, mesothermal, lode-gold deposits in metamorphic terranes constitute a single, coherent group of epigenetic precious met al deposits. Many mesothermal gold deposits in the Quadrilátero Ferrífero (QF) region of Minas Gerais, Brazil are encompassed in the sub-amphibolite to greenschist facies group of Archean, greenstone belt deposits. In general, the hydrothermal alteration of these deposits characterizes a core of Fe-carbonates, normally with micas and albite, grading out into calcite and chlorite. Quartz veining and sulfidation are variably developed, with gold residing mainly within sulfides. Gold mineralizing fluids were $\mathrm{CO}_{2}-\mathrm{H}_{2} \mathrm{O}$-rich, of relatively low salinity, with a near neutral to slightly alkaline $\mathrm{pH}$ and mainly reducing. In the QF, changes in the molar fraction $\mathrm{XcO}_{2}, \mathrm{a}_{(\mathrm{K}+/ \mathrm{H}+)}$ and $\mathrm{a}_{(\mathrm{Na}+/ \mathrm{H}+)}$ controlled the alteration assemblages of metamafic and meta-ultramafic rocks. Chlorite dominates the incipiente, and carbonate the advanced alteration assemblages, suggesting that a $\mathrm{H}_{2} \mathrm{O}$-rich evolved from an original, higer $\mathrm{CO}_{2}: \mathrm{H}_{2} \mathrm{O}$-ratio fluid, typical of the more advanced stages of alteration. Changes in ais and Xco2 controlled Al-poor banded iron formation (BIF) carbonate- and sulfide-alterations. The capacity of BIF mineral assemblage to buffer the incoming fluid $\mathrm{fO}_{2}$ determined 1) the evolving fluid ais (and $\mathrm{XcO}_{2}$ ), and thereby 2) the sulfide paragenesis in physical space, in chemical space and over geological time. Variations in ais and Pfiuid can also be deduced from the gold-associated alteration in BIF. Shear zones are occupied mainly by pyrrhotite, whereas pyrite + arsenopyrite occur as bedding-replacement zones in BIF. The incipient (buffered) and more advanced (unbuffered) stages of alteration reflect the gradual compositional evolution of a relatively uniform, external fluid through interaction with wallrocks, thus reflecting varying fluid versus rock ratios. The hydrothermal alteration and gold precipitation were roughly isothermal, in keeping with temperature and pressure calculations for deposits in other parts of the world. Suggested slight variations inf 02 , $\mathrm{pH}$ and ais in the QF deposits probably played an important role in gold deposition.

Keywords: gold, Quadrilátero Ferrífero, hydrothermal alteration conditions

INTRODUCTION The objective of this paper is dual. Firstly, we intend to provide a thorough review of the critical knowledge base regarding hydrothermal alteration and mineralization processes associated with Archean, mesothermal gold deposits. Secondly, this knowledge base is applied to the context of mesothermal, lode-gold mineralizations in the Quadrilátero Ferrífero, Minas Gerais, Brazil. Thereby, a state-of-the-art integration of hydrothermal alteration and gold mineralization conditions in the Quadrilátero Ferrifero is presented, as well as a critical evaluation of the generalized, gold-mineralizing, fluid conditions.

By far the greatest number of mineral deposits has been formed by precipitation from hydrothermal solutions (Skinner and Barton 1973). Hydrothermal ore deposits form because a hot, aqueous solution carrying met als and other components precipitates minerals in ore traps due to physico-chemical disequilibrium between rocks and fluid (Skinner 1997). Fluids travelling through rocks result in mineral reactions that accommodate such severe disequilibrium, generating new - hydrothermal - mineral associations.

Hydrothermal alteration is a chemical replacement of original minerals in a rock by new minerals where a hydrothermal fluid delivers the chemical reactants and removes the aqueous reaction products. It is a function of variations of temperature, pressure and, most importantly, fluid composition (Reed 1997, Rose and Burt 1979). This chemical interaction between wallrocks and hydrothermal solutions is certainly a major factor in the precipitation of many ores. An understanding of hydrothermal alteration is therefore of value, because it provides insights into the chemical attributes and origins of ore fluids and the physical conditions of ore formation (Reed 1997). Predictive insights regarding orebody geometry and grade can thereby be inferred.

The usefulness of hydrothermal alteration, both as a guide to ore and as an indicator of the character of solutions associated with ore deposition, has been recognized for a long time (Rose and Burt 1979). The significance of wallrock alteration was initially pointed out in the late 1940 's by way of the recognition of the association of ore with zones of serialization, silicification and chloritization.

Since then, the improvements in analytical techniques have broadened the knowledge on the subject via studies in the fields of lithogeochemistry, isotope geochemistry, and fluid inclusions, among others. The fields of isotope and fluid inclusions studies have been of utmost importance in unraveling fluid-rock interaction in fossil and recent geothermal systems and sea-floor deposits. They have also established the role that magmatic, meteoric and metamorphic fluids play in ore deposit models (Appleyard and Guha 1991).

Hydrothermal alteration assemblages display zonal patterns that reflect, from the ore zone to the least altered host rock, progressive rock buffering. Hence, alteration haloes provide a much larger exploration target than the deposits themselves, and are regularly used by most exploration companies in their search for ore (c.f. abstracts in Walton and Jambor 1998).

The study of hydrothermal alteration associated with gold deposition in Archean, mesothermal deposits has received a lot of attention in the literature in the last ten years. Efforts to focus on the alteration assemblages rather than on the vein and ore material alone are certainly

* Instituto de Geociências, CPMTC, Universidade Federal de Minas Gerais, Cx. Postal 719, Av. Antônio Carlos 6627, Pampulha, lobato@igc.ufmg.br,

31270.901, Belo Horizonte, MG

** Mineração Morro Velho Ltda., Fazenda Rapunha s/n, dopl @bismail.com.br, 34000.000, Nova Lima, MG 
adding to the understanding of hydrothermal systems related to mesothermal gold mineralizations (McCuaig and Kerrich 1994).

The literature on the subject is abundant. The reader is invited to consult the reviews by Roberts (1988), Robert et al. (1991), Boyle (1991), Guha et al. (1991), Phillips and Powell (1992, 1993), Groves and Foster (1993), Kerrich (1993a), Hodgson (1993), Herrington et al. (1997), among others.

There is growing body of literature describing mesothermal, lodegold deposits in the Quadrilátero Ferrífero $(\mathrm{QF})$ region, particularly in the case of mineralizations hosted solely by Archean metavolcanosedimentary rocks, some of which focus on hydrothermal alteration. The works by Ladeira $(1980,1988)$, Vieira $(1988,1987$ a, 1991a), Duarte (1991), Souza Filho (1991), Vieira and Simões (1992), Godoy (1994), Abreu (1995), Godoy (1995), Martins Pereira (1995), Pereira (1996), Junqueira (1997), Toledo (1997), Borba (1998), Ribeiro (1998), Ribeiro-Rodrigues (1998), Galbiatti (1999), Menezes (1999), Rolim (1999) and Lobato et al. (1998b, the present volume), among others, inspired the present authors to proffer this contribution. We aim to further improve the understanding of these economically important gold deposits, in light of the phenomenal amount of information made available worldwide, particularly in recent years.

HYDROTHERMAL ALTERATION AND RELATED ORE DEPOSITS Over the past five decades students of ore deposits have come to accept that most ore minerals are concentrated through the permeation of adequately conditioned fluids into porous rock systems. Porosity and permeability may be primary properties of deposition or secondary functions of structural ground preparation (e. g. Bursnall 1989). The concept formed the basis to establish the hydrothermal model applied to mineral deposits, for which the revision by Appleyard and Guha (1991) is an excellent source.

Both the geological setting of hydrothermal mineral deposits and the minerals concentrated within them vary widely. Ore traps are sites where appropriate combinations of structural, chemical, and physical conditions force ore mineral pre- cipitation reactions. The fluid that arrives at the ore trap is not the same as the "primary" or "source" fluid, such as magmatic brine or heated seawater, because wallrock reaction along the transport pathway changes fluid composition (Reed 1997).

The keys to most questions related to the genesis of hydrothermal ore deposits are 1) the source(s) and the physical and chemical characteristics of the ore-forming fluid; 2) the nature of the hydrothermal aquifer and the hydrodynamic force that controls a solution's flow; 3) the mechanisms for dissolving and transporting ore-forming components; and 4) the causes of precipitation from the fluid (Skinner 1997). The source(s) is (are) usually not confidently identified, ranging from the "unknown" source to magmatic, metamorphic, sedimentary (or connate) and meteoric. The influence of wallrock composition on mineral deposition is primarily related to the physical properties of various host rocks in their abilities to sustain variations in permeability regimes (Meyer and Hemley 1967).

The timing of mineralization is universally placed late in the overall geological history, but the recognition that, at places, the ores can be pre-tectonic rather than syn- or late tectonic dates as far back as the 1960 's. In general, ore mineral and sulfide-silicate textures were interpreted as having formed during and because of diagenesis and low-grade metamorphism. It was also recognized that wallrock alteration associated with many sulfide and lode-gold deposits was the result of the metamorphism of hydrothermally altered host rocks rather than the alteration of metamorphic host rocks (Appleyard and Guha 1991).

Pre-tectonically emplaced ores can experience remobilization and substantial geochemical modification by fluids generated during tectonism and metamorphism. This diverges from the formerly accepted hypothesis that the source of the hydrothermal fluids was considered to be purely magmatic, either plutonic, volcanic or deeply evolved and derived. These conclusions resulted from the reformulation of models then applied to massive sulfide and lode-gold-type deposits (Appleyard and Guha 1991).

Wallrock alteration is an important associate of hydrothermal ore deposits because the processes of ore deposition are the same processes that give rise to alteration assemblages (Susak 1994). The mineralogical and chemical changes brought about by reactions of the mineral constituents of rocks with circulating solutions within the host rocks of orebodies are common features of a diversity of ore systems. Just as common are the regular zonal patterns, which reflect changes in the composition of the fluid with time or extent of reaction with rock (Meyer and Hemley 1967). Hydrothermal alteration zones surrounding hydrothermal ore systems (e. g., veins) are therefore manifestations of the extent to which the original wallrocks were out of chemical equilibrium with the fluids that were traversing them (Lindgren 1895 and Knopf 1929, in William-Jones et al. 1994).

ARCHAEAN MESOTHERMAL GOLD DEPOSITS AND ASPECTS OF HYDROTHERMAL ALTERATION Structurally hosted, lode-gold vein systems in metamorphic terranes constitute a single, coherent group of epigenetic precious met al deposits. Examples of this class of epigenetic precious met al vein deposit have variously been called Archean gold, mesothermal gold, gold only or lode-gold.

The term Archean lode-gold-deposit arose because most Archean gold ores belong to this genetic group, relatively abundant in late Archean greenstone belts (Groves 1993, Kerrich 1993b). GebreMariam et al. (1995) suggest the use of the terms epizonal and hypozonal for deposits in the prehnite-pumpellyite to low greenschist, and in amphibolite or lower-granulite facies, respectively, the so-called "mesothermal" deposits being classified as mesozonal. The use of the term "Lode Gold" (Colvine et al. 1984, Roberts 1988) is however preferred as a classification to include the full spectrum of morphological characteristics that Archean gold deposits encompass. In many greenstone belts, these structurally controlled gold deposits are characteristically enriched in Au with variable enrichments in Ag, As, W, $\mathrm{Sb}, \mathrm{Bi}, \mathrm{Te}, \mathrm{B}$ and $\mathrm{Pb}$, but rarely $\mathrm{Cu}$ or $\mathrm{Zn}$.

Most of the lode-gold deposits represent the so-called "mesothermal" deposits hosted in greenschist facies host rocks, a characteristic also described in the QF (Ladeira 1991). There is, nonetheless, a growing realization that significant lode deposits may occur in subgreenschist facies and amphibolite to granulite facies host rocks. This led Groves (1993) to propose that they represent a crustal continuum that formed under a variety of crustal regimes. These range across a crustal profile of at least a $15-\mathrm{km}$ crustal profile at pressure-temperature conditions ranging from $180^{\circ} \mathrm{C}$ at $1 \mathrm{~kb}$ to $700^{\circ} \mathrm{C}$ at $5 \mathrm{~kb}$.

Alteration Assemblages At greenschist to sub-amphibolite facies conditions, there is commonly a wide zone of pervasive carbonate alteration with a central core of ankerite, ferrodolomite or dolomite (less magnesite) grading out into fringes rich in calcite, commonly with associated chlorite. In the strongly mineralized zone, there are normally $\mathrm{K}$-micas, biotite, sericite (less commonly V- or Cr-bearing micas), but these may be absent in Al-poor rocks such as banded iron formation (BIF). In addition, albite and less commonly K-feldspar may be present in volcanic or intrusive host rocks in specific deposits. Quartz veining and silicification are variably developed, and tourmaline may be locally abundant.

Mesothermal, lode-gold deposits are typically hosted by mafic volcanic rocks and by banded iron-formation (BIF) (Phillips et al. 1984). Gold resides within sulfides (mainly pyrite) that replace iron minerals in the altered wallrock immediately adjacent to quartz veins. The alteration assemblages differ in det all from one deposit to another, reflecting different fluid compositions and primary rock types. Despite the variety, the assemblages are remarkably consistent in consisting of pyrite \pm pyrrhotite \pm arsenopyrite, sericite (or biotite), chlorite, albite and $\mathrm{Fe}-\mathrm{Mg}$-Ca carbonates in deposits of all ages, worldwide (Bõhlke 1989, Clark et al. 1989). Heterogeneous distribution of accessory scheelite, tellurides, stibnite, galena, sphalerite, magnetite, hematite and anhydrite may occur. However, carbonatization of the wallrocks dominates both the visible and chemical hydrothermal alteration.

The ubiquity of carbonates makes this deposit type the best example of the occurrence of carbonate alteration, resulting from reaction of wallrock with $\mathrm{CO}_{2}$-rich fluids. In the Archean deposits, the alteration assemblages vary according to parent lithological units but always reflect the transition of $\mathrm{CO}_{2}$ from the fluid to the rock. Components other than $\mathrm{CO}_{2}$ and gold added to the altered rock are $\mathrm{K}_{2} \mathrm{O}, \mathrm{H}_{2} \mathrm{O}$, S and As with either introduction or redistribution of $\mathrm{SiO}_{2}$, and more localized introduction of $\mathrm{Na}_{2} \mathrm{O}, \mathrm{Rb}, \mathrm{Li}$ and $\mathrm{Ba}$. There is a distinctive suite of immobile elements (e. g., Al, Ti, V, Y, Zr) and relatively mobile elements ( $\mathrm{Fe}, \mathrm{Mg}, \mathrm{Cr}, \mathrm{Ni}, \mathrm{Sc}$ ), and there is commonly a volume increase in mineralized zones (Groves and Foster 1993).

Various studies have addressed the hydrothermal alteration using mineralogical and whole-rock composition. The mineralogical expression of this metasomatism can be verified in Table 1 (from Groves and Foster 1993, adapted from Colvine et al. 1988). Host mafic rocks, for example, contain mainly Fe-Mg carbonates whereas calcite predominates in the outer envelopes. This is the case in Kalgoorlie, Australia (Phillips 1986, Lines, 1998) and in Kerr-Addison, Canada (Kishida and Kerrich 1987). For the latter deposit the authors use the molar ratios of $\mathrm{CO}_{2} /(\mathrm{Fe}+\mathrm{Mg}+\mathrm{Ca}),(3 \mathrm{~K}+\mathrm{Na}) / \mathrm{Al}, 3 \mathrm{~K} / \mathrm{Al}$ and $\mathrm{Na} / \mathrm{Al}$ as saturation indices to monitor the various stages of hydrothermal alteration. 
Table L Typical wallrock alteration in and adjacent to lode-gold deposits in greenschist, metamorphic fades domains. In part adapted from Colvine et al (1988).

\begin{tabular}{|c|c|c|c|}
\hline Host rock & Main ore zone & Proximal alleration & Distal alteration \\
\hline Basalt and dolerite & $\begin{array}{l}\text { Quartz-carbonate veining; silification; } \\
\text { ankerite + biotite or sericite, some abite; } \\
\text { rare green mica; abundant Fe-sulfides I } \\
\text { arsenogyrite; stibnite locally abundant }\end{array}$ & $\begin{array}{l}\text { Ankerite-dolomite + biotite or } \\
\text { sericite } \pm \text { high-Mg chlorite; some } \\
\text { Fe-sulfides }\end{array}$ & $\begin{array}{l}\text { Calcite + chlorite + amphibole } \\
\text { +albite; minor Fe-sulfides }\end{array}$ \\
\hline Komatiites and ultramafic sills & $\begin{array}{l}\text { Quartz-carbonate veining; silification; } \\
\text { ankerite-magnesites + phlogopite or } \\
\text { green (V or } C r) \text { mica; abandant Fe- } \\
\text { sulfides and arsenopyrite; stibnite locally } \\
\text { abundant }\end{array}$ & $\begin{array}{l}\text { Dolomite-ankerite-magnesite }+ \\
\text { Talc } \pm \text { phlogopite; minor Fe- } \\
\text { sulfides }\end{array}$ & $\begin{array}{l}\text { Chlorite }+ \text { amphibole + talc- } \\
\text { dolomite-calcite; serpentine } \pm \\
\text { chlorite } \pm \text { talc }\end{array}$ \\
\hline Banded iron formation & $\begin{array}{l}\text { Quartz-carbonate veining; silification; } \\
\text { sulfidation of magnetite or siderite to } \mathrm{Fe} \text { - } \\
\text { sulfides } \pm \text { arsenopyrite }\end{array}$ & $\begin{array}{l}\text { Partial silphidation of magnetite or } \\
\text { siderite to Fe-sulfides; some } \\
\text { chlorite }\end{array}$ & No obvious alteration \\
\hline Granitoids and felsic porphyries & $\begin{array}{l}\text { Quartz veining, intense silicification; } \\
\text { biotite or sericite + calcite; K-feldspar or } \\
\text { albite; Fe-sulfides } \pm \text { arsenopyrite; } \\
\text { chalcopyrite, spharelite, galena, } \\
\text { molybdenite and tourmaline locally } \\
\text { abundant }\end{array}$ & $\begin{array}{l}\text { Sericite } \pm \mathrm{K} \text {-feldspar } \pm \text { albite; } \\
\text { calcite + titanite } \pm \text { tourmaline; } \\
\text { minor } \\
\text { Fe-sulfides }\end{array}$ & $\begin{array}{l}\text { Sericite + calcite; commonly } \\
\text { limited alteration }\end{array}$ \\
\hline
\end{tabular}

Fluid to Rock Dynamics In the review by McCuaig and Kerrich (1994), examples of different districts are used to highlight the mineral characteristics of alteration zones surrounding lode-gold deposits. The hydrothermal alteration assemblages surrounding quartz-dominated veins in fluid conduits, such as shear zones, faults or fracture systems reflect open chemical- and isotopic-system behavior. The metasomatic interaction of fluids with conduit wallrocks occurs during upward advection through the crust, as the fluids approach chemical, isotopic and thermal equilibrium.

The alteration reflects an intricate interplay between rheological behavior, fluid dynamics and chemical and isotopic exchange, involving 1) the tectonic regime; 2) composition of host lithological units; 3 ) composition of the hydrothermal fluid; 4) temperature; and 5) pressure.

The alteration due to fluid to rock interaction occurs by two main processes: 1) infiltration of fluids along local structural discontinuities, such as open fractures and microcracks. This varies from the scale of laterally extensive quartz veins to that of the migration of fluids along mineral grain boundaries; and 2) diffusion of ions through static pore fluids. The dominance of one over the other is controlled by the balance between permeability of the conduit and the diffusion rates along grain boundaries in the wallrock. However, in the case of gold systems, infiltration rates are greater than those of diffusion (Ridley 1990).

The mineralogical composition of alteration assemblages associated with lode-gold deposits is varied. The zonations are observed 1) with increasing distance orthogonally away from fluid conduit(s); 2 ) between host lithological units of differing bulk composition; and 3) regionally with temperature and pressure of formation.

Zones perpendicular to fluid conduits are the commonest. They may range from millimeters to decameters, or more, in thickness, and are identified by the presence of diagnostic mineral assemblages. Inner (proximal) zones reflect fluid-dominated (unbuffered), metasomatic reactions. Zones distant from veins reflect a decreasing gradient of fluid to rock ratio, as well as chemical gradients, and represent progressive infiltration of the fluid into the wallrock. Boundaries between alteration zones may be knife sharp or gradational over centimeters to metets. Shaip boundaries are common m proximal alteration, zones. Diffuse boundaries predominate in distal alteration zones. The most distal alteration zones grade into the least-altered regional metamorphic assemblages.

The greatest complexity occurs mainly in the inner alteration zones due to narrow zone widths and the episodic nature of deformation and fluid infiltration, which act in concert to produce alteration zones with complex crosscutting relationships. These zones are progressive in nature, such that proximal alteration zones overprint their distal counterparts. Within a single, host-rock type, there is little variation parallel to the fluid conduits. However, a fluid conduit in a single deposit that transects two lithological units of contrasting bulk composition will have different mineral assemblages in the different lithological units. Within a single lithological unit in any given deposit, the alteration zones may be traced parallel to the fluid conduits, both down dip and along strike, for hundreds of meters showing little variation in minera- logical composition within individual zones. This indicates relatively isothermal conditions of vein emplacement and metasomatism.

Distal alteration zones are generally ubiquitous throughout the hydrothermal system, but innermost alteration zones may be restricted to fault-fault or fault-lithological contacts, dilatational flexures in structures, or other such areas of extremely high fluid flux. Alteration holds information on intensive ( $\mathrm{P}, \mathrm{T}, \mathrm{X}_{\mathrm{CO} 2}$, etc.) and extensive (fluid flux, mass of ore or gangue) properties of the larger hydrothermal system (McCuaig and Kerrich 1994).

Hydrothermal Alteration Conditions The P-T environment is reasonably well constrained for deposits in the greenschist facies, with deposition occurring in the range of $\mathrm{T}=300$ to $350^{\circ} \mathrm{C}$ and $\mathrm{P}=1$ to $3 \mathrm{~kb}$. For these deposits, the hydrothermal mineral assemblages can completely overprint metamorphic assemblages; both are characteristic of the greenschist facies, but the former does not necessarily reflect retrograde conditions (Phillips 1991, Robert and Sheahan 1991). Wallrock alteration thus post-dates peak metamorphism. Together with gold mineralization, the alteration can be associated with a regional tectono-metamorphic event (Groves and Foster 1993).

Det alled studies of gold alteration envelopes in mafic and ultramafic host rocks have shown that the zoning of mineral assemblages reflects a decrease in $\mathrm{CO}_{2}$ of the fluid away from the ore. It has been shown that decreasing $\mathrm{CO}_{2}: \mathrm{H}_{2} \mathrm{O}$ ratio in the fluid controlled the development of four distinct progressive alteration phases from the goldbearing zone outward (Dubé et al. 1987). This hydrothermal alteration pattern can be derived from a single fluid with a higher initial $\mathrm{CO}_{2}: \mathrm{H}_{2} \mathrm{O}$ ratio, evolving as a result of interaction with host rocks.

The nature of the ore fluids has been deduced from fluid inclusion studies of quartz veins interpreted to be synchronous with, or slightly post-dating, the main stage of gold mineralization. They indicate that for most deposits, gold mineralizing fluids were rich in $\mathrm{CO}_{2}-\mathrm{H}_{2} \mathrm{O}$, generally with $10-25 \mathrm{~mol} \% \mathrm{CO}_{2}$, of relatively low salinity (typically 3-6 vol. $\% \mathrm{NaCl}$ equivalent), and moderate density $\left(0.3-0.9 \mathrm{~g} / \mathrm{cm}^{3}\right.$, typically 0.8 . The fluid is considered to have been near neutral to slightly alkaline and mainly reducing, with small (1, commonly 0.1 mol \%) concentrations of $\mathrm{CH}_{4}$ having been detected, although oxidized fluids have also been recorded. A. similar concentration of $\mathrm{N}_{\mathrm{a}}$ is also present. Minimum gola aepositional conditions are $200-400^{\circ} \mathrm{C}$ (mainly $250-350^{\circ} \mathrm{C}$ ) and $0.5-4.5 \mathrm{~kb}$ (mainly $0.8-3 \mathrm{~kb}$ ).

Various degrees of phase separation are recorded, but it is only rarely that saline aqueous fluids are recognized. Water dominates the ore fluids (75-90 mol \%), whereas $\mathrm{CO}_{2}$ usually constitutes 10-25 mol $\%$. The gases most commonly detected are $\mathrm{CO}_{2}, \mathrm{H}_{2} \mathrm{~S}, \mathrm{H}_{2}$ and $\mathrm{CH}_{4}$, and also the relatively non-reactive species $\mathrm{N}_{2}$, He and Ar. Stable-isotope data for quartz, carbonate and sulfide from various deposits are also remarkably similar. The range of calculated $\delta^{18} \mathrm{O}_{\mathrm{H} 20}$ values of the ore fluids, based on the isotopic composition of the dominant type of vein quartz, are typically between 4.5 and $7 \%$. These values are compatible with either a magmatic or a metamorphic derivation (see revisions by Groves and Foster 1993, Hodgson 1993, De Ronde et al. 1997, and references therein). As mentioned by Groves (1993), there is an increasing body of fluid-inclusion and stable-isotope evidence to sup- 
port the involvement of surface waters in upper levels (lower- or sub-greenschist) settings.

Origin Of Archean Mesothermal Gold Deposits Research into the origin of gold deposits has probably attracted more hypotheses throughout history than any other mineral-deposit type, and deposits of the Archean are no different (Herrington et al. 1997). There is a broad consensus of an epigenetic origin for Archean gold deposits. Despite this, gold-rich, sulfide-BIF mineralizations have been used to provide evidence fora syngenetic origin (Fripp 1976, in Kerrich 1993). This was later refuted by Phillips et al. (1984), who related their origin to the propensity of these very iron rich rocks to fix sulfide alteration. One major problem in developing a consistent model for the formation of all these gold deposits is the above-mentioned, broad range of interpreted formation conditions (Col vine et al. 1988, Groves 1993). The associated, intense alteration indicates a massive fluid flux, and the simple mineralogical composition of the alteration is perhaps further evidence for a large, open metasomatic system with high fluid flux (Groves 1993). According to the revision by Herrington et al. (1997), the weight of evidence appears to point to a deep, probably metamorphogenic fluid source model, despite the indication that mineralization post-dates peak metamorphism. Kerrich (1991) argues that in collisional belts, where crustal thickening is essentially instantaneous with respect to thermal relaxation, peak metamorphism at $60-\mathrm{km}$ depth may post-date the peak at $10 \mathrm{~km}$ by up to $40 \mathrm{Ma}$. The same author in 1993 also indicates that younger ages of mineralization in relation to metamorphism (as much as $\sim 100 \mathrm{Ma}$ ) may reflect secondary disturbance of the primary ore. The broad range of $\mathrm{T}$ and $\mathrm{P}$ conditions for deposit formation, discussed by Groves (1993), suggests a very deep crustal, possibly sub-greenstone-belt source for the gold bearing fluids, but with some component contributions from other, possibly crustal and orthomagmatic sources.

GOLD-RELATED HYDROTHERMAL ALTERATION WITHIN ROCKS OF THE NOVA LIMA GROUP: WHAT WE KNOW The Quadrilatero Ferrifero (QF) is located in the southernmost São Francisco Craton (Almeida and Hasui 1984) in southeastern Brazil. The São Francisco Craton is limited by Brasiliano-age (700-450 Ma) mobile belts, and is constituted by a basement consolidated during the Archean and Eoproterozoic. The geological units of the QF embody 1) granite-gneissic terranes of Archean age; 2) Archean greenstone belts of the Rio das Velhas Supergroup and other related successions; and 3) Eo- and Mesoproterozoic, metasedimentary units of the Minas Supergroup, the Itacolomi Group and the Espinhaço Supergroup (Dorr 1969).

A more det alled account of the geology of QF region is reviewed by Lobato et al. (1998b, the present volume). Endo (1997), Toledo (1997) and Zucchetti (1998) also provide excellent reviews of the present knowledge of QF geology.

The QF was the most productive gold region in Brazil in the IS" ${ }^{1}$ century. The most important gold deposits are located in the northern portion of the QF, embodying for example the Cuiabá, Morro Velho (Grande and Velha), Raposos, São Bento, Faria, Bicalho and Bela Fama mines, hosted by rocks of the Nova Lima Group. Lode-gold mineralization at Santana is located along the sheared contact between rocks of the Minas Supergroup (Itabira Group) and schists of the Nova Lima Group (see Ladeira 1991).

Lobato et al. (1998b, the present volume) review the styles of hydrothermal alteration and mineralization of epigenetic, structurallycontrolled gold deposits in the QF, associated with rocks of the Nova Lima Group. These are the Cuiabá, Jucá Vieira, Raposos, Santana and São Bento deposits. The most important conclusions arising from these investigations incorporate the following most important characteristics:

(1) Alteration assemblages replace pre-alteration (metamorphic) associations, pointing to their syn- to post-peak metamorphic development age. They are dominated by quartz, carbonate, K/Na-mica, feldspar (albite), $\mathrm{Fe} / \mathrm{Mg}$-chlorite, pyrite, pyrrhotite, arsenopyrite, \pm tourmaline;

(2) Pervasive carbonate alteration has a core of Fe-ankerite/ankerite, intermediate ferrodolomite or dolomite grading out into fringes rich in calcite and/or siderite (BIF). In BIF, carbonate alteration (mostly ankerite) is particularly prominent and sulfide layers are the result of sulfidation of quartz-carbonate-magnetite BIF layers;

(3) Mineral reactions of the incipient alteration stage suggest reducing hydrothermal fluid. The evolution from a carbonate-(advanced stage) to a chlorite-dominant (incipient stage) assemblages indicates an initial $\mathrm{CO}_{2}: \mathrm{H}_{2} \mathrm{O}$-fluid, evolved to lower (chlorite) $\mathrm{CO}_{2}: \mathrm{H}_{2} \mathrm{O}$ ratios;
(4) Unbuffered assemblages in the proximity to ore indicate infiltration of a large volume of external fluid. The zonation of alteration types reflects evolution in the composition of the fluid through interaction with wallrocks. Large fluid volumes under conditions of high $\operatorname{Pr}$ favored the large-scale recrystallization and precipitation along shear-induced permeabilities;

(5) $\mathrm{S}, \mathrm{CO}_{2}, \mathrm{As}, \mathrm{Au}$ are added during the alteration, and $\mathrm{SiO}_{2}$ is either stable or lost. $\mathrm{CO}_{2}$ addition is constant and the saturation index $\mathrm{CO}_{2} /\left(\mathrm{Ca}+\mathrm{Fe}^{2+}+\mathrm{Mg}+\mathrm{Mn}\right)$ is useful as a measure of alteration degree;

(6) Gold is closely related to wallrock alteration. Its deposition occurred simultaneously with sulfide precipitation. In BIF-hosted mineralizations it must have occurred due to fluid-wallrock sulfidation reactions. This close association suggests that reduced sulfur complexes were the predominant transport mechanism

(7) In the case of gold bearing carbonate and sericite alteration zones, and associated quartz veins, involving cation and or $\mathrm{H}+$ consuming reactions (Jucá Vieira and Santana Mines), $\mathrm{pH}$ variations may have been in part responsible for gold precipitation.

DISCUSSION: INFERRED CONDITIONS OF HYDROTHERMAL ALTERATION IN THE QUADRILÁTERO FERRIFERO This paper reviews the state of the art relating to hydrothermal alteration associated with mesothermal, lode-gold deposits, particularly those hosted by rocks holding mineral assemblages of the subamphibolite and greenschist facies of metamorphism. It is shown that the alteration associated with different lithological units imposes varying mineralogical associations in zonal patterns enveloping gold ore. Such associations reflect original fluid composition, and the fluid's compositional evolution, owing to fluid to rock interaction in structurally controlled pathways. The zonal pattern reflects varying fluid to rock ratios under roughly isothermal conditions.

The deposits described by Lobato et al. (1998b, present volume) are either replacement-dominated (BIF-hosted mineralizations at the Cuiabá, Raposos and São Bento) or disseminated in zones of hydrothermal alteration (carbonate-sericite) associated with quartz veins (e. g. Jucá Vieira and Santana Mines).

The origin of these deposits is controversial and much has been said about their epigenetic versus syngenetic attributes (Fleisher and Routhier 1973, Vial 1988, Vieira and Oliveira 1988, Duarte, 1991, Ladeira 1991, among others). It is beyond the scope of this review to dwell on the subject. Identifying a single, coherent model for the mesothermal gold deposits in the $\mathrm{QF}$ is a monumental task. It requires an integrated interplay of knowledge relating to regional and local geological information, geochronology, structural geology, petrography and mineralogy, whole-rock geochemistry, radiogenic and stable isotopic signatures, fluid inclusions, geothermometry and geobarometry.

So much of this information is not available yet, but an increasing number of workers are currently contributing to the already voluminous body of existing data, some of which are referenced herein.

We aim to quantify some the critical parameters that brought to bear on the hydrothermal alteration systems associated with the terrain's gold mineralizations, on the basis of the foregoing review of the state of the art of hydrothermal alteration in Archean, mesothermal, gold-ore systems.

What can we gather about fluid generation and composition, based on the information on hydrothermal alteration and fluid inclusion (and isotope) studies? How do fluids associated with mesothermal gold deposits in the QF compare to fluids attributed to deposits in similar host rocks in cratons in Australia, Africa, Canada, and India? How could fluid composition have influenced gold deposition? These are the topics we wish to review. By doing so, we aim to contribute effectively to an eventual, integrated model of gold mineralization in the region and elsewhere.

Fluid Inclusion and Isotopic Studies The studies by Godoy (1994) for the Raposos Mine identify three types of fluid inclusions, based on microthermometric and spectroscopic studies using Raman. Type I inclusions are abundant in the ore and composed of $\mathrm{H}_{2} \mathrm{O}, \mathrm{CH}_{4}$, $\mathrm{N}_{2}$, and a smaller proportion of $\mathrm{CO}_{2}$. Type II occurs in tension gashes and has $\mathrm{H}_{2} \mathrm{O}, \mathrm{CO}_{2}$ and $\mathrm{NaCl}$, with lesser $\mathrm{CH}_{4}$. Type $\mathrm{HI}$ is an aqueous, saline fluid. Type I is interpreted as the initial, more reducing, mineralizing fluid. Type II is related to carbonate alteration (probably evolved from I) and type III to late, brittle deformation structures. The $\mathrm{P}$ and $\mathrm{T}$ of gold mineralization of $3.5 \mathrm{~kb}$ and $400^{\circ} \mathrm{C}$, respectively, take into consideration type I inclusions and temperatures of formation for arsenopyrite and chlorite. Phase separation between a liquid and a gas is also indicated by Godoy (1994). 
Fluid inclusions in mineralized and barren quartz veins in the São Bento Mine have been studied by Alves et al. (1992), Alves (1995) and Alves et al. (1997). These studies indicate the presence of $\mathrm{H}_{2} \mathrm{O}+$ $\mathrm{CO}_{2}+\mathrm{CH}_{4}\left( \pm \mathrm{N}_{2} \pm\right.$ HS- $)$ and $\mathrm{CH}_{4}+\mathrm{N}_{2}$ ( \pm HS- $)$ fluids which were possibly related to $\mathrm{Au}$ transport and deposition. $\mathrm{CH}_{4}$ is the predominant gas phase of type $2\left(\mathrm{CH}_{4}+\mathrm{N}_{2} \pm \mathrm{HS}-\right)$ inclusions, considered to be representative of the most primary fluid signature.

Type 1 inclusions are aqueous, nitrogenous and carbonic, and their evolution from la to Ic indicates a path from least (primary) to most evolved fluid composition. There is a decrease in the carbonic phase from $10-15 \%$ to $5 \%$ (la to Ic). This phase in inclusions la is $\mathrm{CH}_{4}$-rich (molar volume of $50 \%$ ), with a $\mathrm{CO}_{2}$-equivalent density of $1.05 \mathrm{~g} / \mathrm{cm}^{3}$, and minimum $\mathrm{T}$ and $\mathrm{P}$ of $\sim 300^{\circ} \mathrm{C}$ and $3.2 \mathrm{~kb}$, respectively. The path of fluid evolution is indicated by $\mathrm{CO}_{2}$-richer (up to $88.11 \%$ ) inclusions (types $\mathrm{Ib}$ and $\mathrm{c}$ ), with lower $\mathrm{CO}_{2}$-equivalent density of $0,76 \mathrm{~g} / \mathrm{cm}^{3}$ and lower minimum $\mathrm{T}$ and $\mathrm{P}$, around $\sim 200^{\circ} \mathrm{C}$ at $1 \mathrm{~kb}$. The most evolved fluid composition, identified in association with white mica, is practically pure $\mathrm{CO}_{2}$. The carbonic phase also contains $\mathrm{N}_{2}$ and HS-, and more rarely $\mathrm{H}_{2} \mathrm{~S}$. Their aqueous phase has a salinity in the range of 3.4 to 5.0 vol. \% $\mathrm{NaCl}$ equivalent. Salinities estimated for most other deposits worldwide are typically $1-10 \mathrm{vol} . \% \mathrm{NaCl}$ equivalent.

Carbonic species in aqueous-carbonic fluids associated with lodegold deposits range in $\sim 10-30 \% . \mathrm{CO}_{2}$ varies from almost pure to mixtures containing near-equal proportions of $\mathrm{CO}_{2}$ and $\mathrm{CH}_{4}$ (Mikucki and Ridley 1993). Alves et al (1997) indicate similar values. In la inclusions $\mathrm{CO}_{2}$ varies from approximately 42 to $73 \%, \mathrm{CH}_{4}$ from 10 to $40 \%$ and $\mathrm{N}_{2}$ from almost nothing to $29 \%$. In Ic inclusions $\mathrm{CO}_{2}$ varies from approximately 17 to $88 \%, \mathrm{CH}_{4}$ from none to $46 \%$ (mostly around 10 to $15 \%$ ) and $\mathrm{N}_{2}$ from 6 to $59 \%$.

The evolution from an initially reducing fluid to a more oxidizing condition is interpreted by Alves (1995) as resulting from varying / 02 , via reactions such as $\mathrm{CH}_{4}+2 \mathrm{O}_{2} \rightarrow \mathrm{CO}_{2}+2 \mathrm{H}_{2} \mathrm{O}$. The presence of both HS-, and more rarely $\mathrm{H}_{2} \mathrm{~S}$, suggests that at least some of the fluid evolutionary path involved a near-neutral $\mathrm{pH}$. A possible immiscibility between type-2 and type-1 fluids is also indicated.

Fluid inclusions studies in the Cuiabá Mine are reported by Toledo et al. (1998). Primary-like inclusions are predominantly aqueous, with a bubble occupying 10-15 vol.\% of the inclusion cavity. The fluids were then homogeneous (not immiscible) at the time of trapping. The gas is composed solely of $\mathrm{CH}_{4}$, and $\mathrm{CO}_{2}$ is subordinate. Raman microspectroscopy confirmed the presence of $\mathrm{CH}_{4}$ and $\mathrm{CO}_{2}$, and revealed peaks for $\mathrm{N}_{2}$ and traces of $\mathrm{H}_{2} \mathrm{~S} / \mathrm{HS}$-. Salinity values for the aqueous phase were constrained between 5.9 and $8.0 \mathrm{wt} \%$ eq. $\mathrm{NaCl}$. The authors suggest that evolution of both $\mathrm{CH}_{4}$ and $\mathrm{CO}_{2}$ resulted from hydrolysis of the carbonaceous matter with consequent sharp decrease in $\mathrm{JO}_{2}$ (see $\mathrm{O}_{2}$ and $\mathrm{S}$ evolution in $\mathrm{QF}$ ).

DeWitt et al. (1994) studied the gas composition of fluid inclusions from a variety of quartz veins at São Bento and showed that most formed in place from siderite-rich BIF during regional metamorphism.

Ladeira (1980) determined oxygen isotope values for quartz from lapa seca, as well as for schists hosting gold in the Morro Velho Mine. In a variety of rock types, quartz values vary from 15.96 to $17.36 \%$ c, within similar ranges for whole-rock $\delta^{18} \mathrm{O}$ of schists. The author indicates that the values suggest isotopic equilibrium with submarine fluids, relating to a syngenetic, exhalative hydrothermal alteration. Vial et al. (1987) re-interpret these results and propose the lapa seca to be a suite of volcanic and volcaniclastic rocks, metamorphosed and hydrothermally altered.

Carbonate isotopic studies in metapelites indicate an organic origin for carbon. The results vary from $-18 \% 0$ at the Raposos Mine (Godoy 1994), to -20 to $-25 \%$ o at the Morro Velho and Cuiabá Mines (Fortes et al. 1994).

Carbon isotope values (Godoy 1994) in carbonate from various rock types at the Raposos Mine indicate two main groups of distinct isotopic ratios. Values around zero for mafic rocks not affected by hydrothermalism, and from -4 to $-6 \%$ o for mineralized, hydrothermally altered BIF, mafic and ultramafic rocks. According to this author, the former values are compatible with isotopic equilibrium with submarine fluids, whereas the latter suggest carbonates formed in the presence of fault-controlled hydrothermal fluids. The author hence interprets these results as originating from isotopic homogenization, reinforcing a hydrothermal origin for BIF carbonate, $\delta^{13} \mathrm{C}$ of lode-gold deposits of all ages can be considered to encompass a range of values from $-11 \%$ o to $+2 \%$ c. These are not uniquely diagnostic of any carbon source (McCuaig and Kerrich 1994).
Hydrothermal Alteration and Controls of Fluid to Rock Interaction The alteration assemblages described by Lobato et al. (1998b, the present volume) are the result of mineral reactions between host rocks and the infiltrating, ore-forming fluid (Vieira 1991a, Pereira 1996, Junqueira 1997, among others). They reflect conditions of formation ranging from low to high fluid to rock ratios. Although these reactions do not reproduce the complex hydrothermal processes in all their det alls, they can be used to infer the controls of fluid to rock interaction, particularly for the case of metamorphosed mafic and ultramafic wallrocks.

The incipient stage of alteration of these rocks is dominated by the formation of hydrous minerals (chlorite, talc). Carbonate is also important, but its proportion is significantly augmented only in the advanved stages of alteration.

Alteration assemblages of the incipient stage of alteration vary according to changes in $\mathrm{X}_{\mathrm{CO} 2}$ under isothermal conditions, fully compatible with temperature calculations for these systems (see next section). Hydrothermal reactions involving carbonate formation from metamorphic albite are dependent on $\mathrm{X}_{\mathrm{CO} 2}$ and $\mathrm{fl}(\mathrm{K}+\mathrm{Na}+)$ - Under conditions of low $\mathrm{X}_{\mathrm{C} 02}$ this reaction is dependent on small changes of $\mathrm{X}_{\mathrm{C} 02}$; at high $\mathrm{X}_{\mathrm{CO2}}$ it is more sensitive to variations of $\mathrm{a}_{(\mathrm{K}+\mathrm{Na}+)}$.

In spite of the indicated fluctuations in $\mathrm{X}_{\mathrm{C} 02}$, typical alteration assemblages for the incipient stage can be interpreted to reflect differences mainly in the chemical composition of the parental rocks.

The development of alterations zones containing larger proportions of carbonate, muscovite ( \pm paragonite) and albite characterize a more advanced hydrothermal alteration stage, implying addition of $\mathrm{CO}_{2}, \mathrm{~K}$ and $\mathrm{Na}$ from the fluid, with resultant $\mathrm{H}_{2} \mathrm{O}$ and $\mathrm{H}^{+}$loss. They are a consequence of the replacement of chlorite and initial carbonates. Zones of carbonate-white mica alteration depend on $\mathrm{X}_{\mathrm{CO}} 2$. and activities of $\mathrm{KVH}+$ and $\mathrm{Na}+/ \mathrm{H}^{+}$(see discussion about $\mathrm{pH}$ variation and Mikucki and Ridley 1993, Fig. 1). Sulfidation is intimately related to these zones, and occurred when part of the iron of chlorite reacted with sulfur from the fluid.

The progressive hydrothermal alteration of the Al-poor BIF is not well constrained. Nevertheless, it is clear from textural observations at the Raposos Mine (Lobato et al. 1998a) that progressive replacement of siderite and magnetite by ankerite and pyrrhotite is concomitant, although ankerite, together with some siderite, seems to appear first. Carbonate and sulfide alterations are recurrent. Pyrite and arsenopyrite overgrow pyrrhotite. Rare chlorite appears when pyrrhotite appears. Small amounts of euhedral albite and muscovite bands are present in the advanced stage of sulfide substitution (gold-rich ore).

Phillips et al. (1984) relate the pervasive nature of sulfidation in $\mathrm{BIF}$ to their very iron rich composition. Hence, the mineral transformations in BIF are sensitive to $X_{\mathrm{CO} 2}$ and most importantly to $a_{\text {is. }}$. Nevertheless, the presence of albite and white mica also suggest some dependence on $\mathrm{a}_{(\mathrm{k}+\mathrm{H}+\mathrm{H}}$ and $\mathrm{a}_{(\mathrm{Na}+\mathrm{H}+)}$

As indicated, wallrocks tend to have similar gross mineral assemblages, regardless of the original chemical composition of the parental rocks. Proximal zones of hydrothermal alteration reflect fluid-dominated (unbuffered), metasomatic reactions. This suggests that the original mineralogical and chemical composition adapted to the composition of the infiltrating fluid. On the other hand, hydrothermal alteration zones distant from ore reflect low gradient of fluid to rock ratio, as well as chemical gradients.

The incipient and more advanced stages of alteration can be interpreted in terms of gradual evolution of the composition of a relatively uniform, external fluid through interaction with wallrocks.

Hydrothermal Alteration and Fluid Composition Mikucki and Ridley (1993) discuss ore fluid composition and fluid's compositional evolution of Archean lode-gold deposits at different metamorphic grades. Considering the wealth of information on the lode-gold deposits in the QF much can be inferred in light of these authors' thermodynamic interpretations.

Mikucki and Ridley (1993) show that deposits characterized by sericite, ankerite, dolomite, quartz, albite alteration, with pyrite and arsenopyrite, range from 250 to $350^{\circ} \mathrm{C}$. Those with ankerite, dolomite, calcite, quartz, biotite and albite alteration, with pyrite, pyrrhotite and arsenopyrite are in the 320 to $420^{\circ} \mathrm{C}$ temperature bracket.

The temperature $(\mathrm{T})$ and pressure $(\mathrm{P})$ brackets suggested for some of the QF mesothermal deposits are taken from fluid inclusion studies and arsenopyrite geothermometry, the results from the former studies having already been presented. Arsenopyrite thermometry carried out in the Cuiabá Mine indicates that the T of alteration was from $250^{\circ} \mathrm{C}$ 
to $520^{\circ} \mathrm{C}$ and gold deposition occurred between $270-300^{\circ} \mathrm{C}$ (RibeiroRodrigues 1998).

The gold deposits described by Lobato et al. (1998b, the present volume) can be envisaged in the P-T regime of the greenschist to sub-amphibolite metamorphic facies.

MAJOR COMPONENTS Relatively $\mathrm{CO}_{2}$-rich, aqueous ore fluids have long been recognized as characteristic of sub-amphibolite facies lode-gold deposits (Dubé et al. 1987).

Estimates of $\mathrm{X}_{\mathrm{C} 02}$ of the initial ore fluid from both thermodynamic and fluid inclusion measurements indicate a range of $0.05-0.25$. Variations in $\mathrm{CO}_{2}$ gradients control alteration-zoning patterns in lode-gold deposits.

Mikucki and Ridley (1993, Fig. 1) show that in the case of an ultramafic composition (A- least altered, ultramafic host rock), zones of progressive carbonate alteration encompass associations with Btalc-chlorite, C- biotite, D- fuchsite (gold-bearing zone). Log («coaraq)) for $\mathrm{A}$ is $\sim 0.05-0.25$, for $\mathrm{B}$ it is $\sim 0.4-0.9$, for $\mathrm{C} \sim 1.1-1.2$ and for $\mathrm{D} \log$ $\left(<3_{\mathrm{c} 0} 2(\mathrm{aq})\right)$ is about 1.2 to 1.4 . The $\mathrm{X}_{\mathrm{C} 02}$ values of 0.10 to 0.25 overlap the $\mathrm{C}$ to $\mathrm{D}$ alteration assemblages. These values refer to $\mathrm{T}$ of $350^{\circ} \mathrm{C}$ and total pressure $\mathrm{P}_{\mathrm{t}}=\mathrm{P}_{\mathrm{C} 02}+\mathrm{P}_{\mathrm{H} 2 \mathrm{O}}={ }^{2 \mathrm{~kb}}$ -

Major-component evolution in OF gold-mineralizing fluids In BIFhosted mineralizations such as those at Raposos and São Bento, sulfide layers are the result of sulfidation (pyrrhotite, pyrite, arsenopyrite) of quartz-carbonate (mostly siderite)-magnetite layers. Sulfidation is accompanied mainly by strong carbonate (ankerite) alteration (Pereira Martins 1996, Junqueira 1997, Ribeiro-Rodrigues 1998). Other aspects of BIF alteration include restricted development of sericite, albite and less chlorite. In the case of Cuiabá, carbonaceous matter was also involved (see below).

This mineral assemblage suggest a $\mathrm{H}_{2} \mathrm{O}-\mathrm{CO}_{2}-\mathrm{H}_{2} \mathrm{~S}$ fluid (see also Phillips et al. (1984). Estimates of the initial fluid composition also indicate the presence of higher than usual $\mathrm{CH}_{4}$ and $\mathrm{NaCl}$, attesting the reducing, slightly saline fluid character (Godoy, 1994, Alves 1995, Toledo et al. 1998).

The recurrent nature of carbonate-sulfide alteration suggests fluctuations in the $a_{\Sigma S}: a_{\mathrm{CO} 2}$ ratio. At Raposos, sulfide alteration seems to dictate the shear-dominated, gold-mineralizing zones thereby indicating an increase in the fluid $a_{5 s}: a_{\mathrm{CO} 2}$ ratio with the advancement of hydrothermal alteration.

Subordinate gold mineralization in mafic metavolcanic and metasedimentary rocks is also epigenetic, syn-tectonic. At Raposos, alteration zones of metamafic and meta-ultramafic rocks enveloping ore involve initial breakdown of epidote and/or actinolite, with nucleation of chlorite and Fe-carbonates plus sulfídes (Junqueira 1997). This indicates that a incipient stage of alteration, having evolved from an initial reducing fluid, characterized by a higher $\mathrm{CO}_{2}: \mathrm{H}_{2} \mathrm{O}$ ratio, typical of the advanced stage.

The mineralogical composition of meta-ultramafic alteration zones at the Raposos Mine (Lobato et al. 1998b, the present volume, Fig. 7a) are similar to zones A to D described by Mikucki and Ridley (1993).

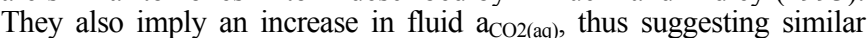
$\mathrm{a}_{\mathrm{CO} 2(\mathrm{aq})}$ variations with the advancement of the alteration and proximity to ore.

The Jucá Vieira and Santana mineralizations also fall within the epigenetic model that Hodgson (1993) classifies as shear-related, mafic- or sediment-hosted disseminated sulfides. Gold is closely related to wallrock alteration and is simultaneously enriched in zones of carbonate, sericite, and tourmaline alteration (mainly Santana Mine), together with quartz and sulfídes (Menezes 1996, Pereira 1996). As in the case of the Raposos Mine too, Vieira (1991a) and Pereira (1996) propose an $\mathrm{H}_{2} \mathrm{O}-\mathrm{CO}_{2}$ fluid. It varies from a predominantly $\mathrm{H}_{2} \mathrm{O}$-dominated fluid in the incipient stage of alteration (chloritization) to a higher $\mathrm{CO}_{2}: \mathrm{H}_{2} \mathrm{O}$ ratio in the most advanced stages of hydrothermal alteration.

OXIDATION STATE ( $\mathrm{fO}_{2}$ AND TOTAL SULFUR CONTENT ( $a_{\Sigma S}$ ) Redox reactions tend to occur when two phases with different oxidation states come in contact. Redox conditions of alteration assemblages vary between lode-gold deposits. Most deposits that contain pyrite \pm arsenopyrite \pm pyrrhotite formed from relatively reduced ore fluids, withyO $\mathrm{O}_{2}$ above or near that of the $\mathrm{CO}_{2}-\mathrm{CH}_{4}$ redox buffer. Fluids of the majority of ore deposits studied to date display $\log \mathrm{fO}_{2}$ in the range $0.5-3$, above the $\mathrm{CO}_{2}-\mathrm{CH}_{4}$ stability curve. Total sulfur concentration in the ore fluids are in the range of $\sim 10$ to $10^{-3} .5 \mathrm{~m}_{\Sigma \mathrm{S}}$, with a trend towards lower sulfur contents at lower $\mathrm{T}$.

Figure 1 displays the range in $\log \mathrm{fO}_{2}$ and $\mathrm{a}_{\mathrm{is}}$ for deposits in the $350^{\circ} \mathrm{C}$ and $2 \mathrm{~kb}$ range. The 'oxidized' fluid field embodies some of the largest gold camps currently known (e. g. the Golden Mile, Kalgoorlie
- $1285 \mathrm{t} \mathrm{Au}$ produced; Phillips 1986). Their range of $\mathrm{m}^{\wedge}$ is around $10^{13}{ }_{-}^{4}$, constrained by the $\mathrm{\Sigma SO}_{4}-\mathrm{H}_{2} \mathrm{~S}$ buffer curve and pyrite-chalcopyrite stability curve.

The lower, 'reduced' fluid conditions can be applied to the QF deposits. The reduced-type fluids have $m_{\Sigma S}$ values roughly between the minimum values for the pyrite-arsenopyrite stability and the intersection of the arsenopyrite and $\mathrm{CO}_{2}-\mathrm{CH}_{4}$ boundary curves $\left(\sim 10 \sim^{2}-10-\right.$ $\mathrm{m}_{\Sigma \mathrm{S}}$ at $350^{\circ} \mathrm{C}$; Figure 1). At lower $\mathrm{T}$, the minimum values are somewhat lower, at $10-^{3}-4$

Figure 2 shows the fields of oxidation state and temperature inferred for known Archean lode-gold deposits.

Oxygen and sulfur evolution in QF gold-mineralizing fluids The common coexistence of pyrite + pyrrhotite + chalcopyrite + arsenopyrite and carbonates in most QF gold-bearing, alteration domains denotes that $f_{2}$, reduced sulfur and $\mathrm{CO}_{2}$ (and the activities of other components) were internally buffered via mineral reactions (Henley et al 1984, Mikucki and Ridley 1993). The mineral transformations tell us much about the apparent sequence of buffering reactions.

Overall $\mathrm{fO}_{2}$ and/or $a \%$ buffering can be deduced from textural evidence in metamafic rocks that suggests that pyrite is replaced by pyrrhotite, which is itself replaced by pyrite (Pereira 1996). Additional textural evidence of specific oxide-sulfide and sulfide-sulfide substitutions is necessary to better constrain these variables.

As pointed out by Fyfe et al. (1978), the principal multicomponent gas system of interest for metamorphic fluids is the C-O-H system. Species other than $\mathrm{CO}_{2}$ and $\mathrm{H}_{2} \mathrm{O}$ are particularly important when graphite is present in metasedimentary rocks. The presence of graphite controls_fO $\mathrm{fO}_{2}$ through the equilibria: $\mathrm{C}+\mathrm{O}_{2} \longrightarrow \mathrm{CO}_{2}$, and the calculations of gas compositions in the $\mathrm{C}-\mathrm{O}-\mathrm{H}$ system indicate high concentrations of $\mathrm{CH}_{4}$ below about $500^{\circ} \mathrm{C}$; methane will be only a minor constituent of C-O-H fluids in the absence of graphite. Although sulfur is an additional component, its partial pressure is quite small. It is during hydrothermal alteration that sulfur fugacity may change appreciably through fluid-rock interaction, hence influencing the stabilities of oxide, sulfide and carbonate mineral phases considerably.

The oxidation state of the original ore fluid in the QF deposits was low. This is inferred from alteration reactions and fluid inclusion studies. In the incipient stage of hydrothermal alteration the $\mathrm{Fe}^{3+}$-bearing phases, epidote in metamafic rocks and magnetite in BIF, are reduced to give way to $\mathrm{Fe}^{2+}$-dominant phases (sulfídes, chlorite, carbonate). It is clear that under unbuffered conditions, both transformations can lead respectively to epidote and magnetite disappearance, hence evolving fluids of slightly higher $f_{2}$ conditions. This is confirmed by the evolution of Type 1 fluid inclusions for the São Bento Mine, from relatively rich in $\mathrm{CH}_{4}$ (la) to later $\mathrm{CO}_{2}$-dominated (Ic) inclusions, indicating that the reaction $\mathrm{CH}_{4}+2 \mathrm{O}_{2}-\mathrm{CO}_{2}+2 \mathrm{H}_{2} \mathrm{O}$ may have taken place (Alves 1995), regardless of the amount of $\mathrm{CO}_{2}$ introduced from the external source. In this case, the molar fraction $\mathrm{X}_{\mathrm{C} 02}$ was indirectly also a function ofy $\mathrm{O}_{2}$.

In Cuiabá, Raposos and São Bento, sulfidation of BIF resulted in variations in the percentage of ever-present pyrite, arsenopyrite and pyrrhotite, forming gold-bearing, sulfide enrichments. At Raposos and São Bento the principal reactions in BIF involved nucleation of carbonates and sulfídes (mainly pyrrhotite) from siderite and magnetite, indicating the dependence of $\mathrm{fO}_{2}, \mathrm{CO}_{2}$ and reduced sulfur. The species HS-, and more rarely $\mathrm{H}_{2} \mathrm{~S}$, were detected in the fluid inclusion studies.

Observation of Figure 1 reveals that under conditions of fixed (buffered) $\mathrm{fO}_{2}$, siderite and magnetite replacement by pyrrhotite is a function of $\log \mathrm{a}_{\Sigma \mathrm{s}}$. In a hydrothermal system where large amounts of externally generated, sulfur-rich, reducing fluids encounter magnetite and siderite, the reaction to pyrrhotite provides a convenient sink to buffer fluid $\mathrm{fO}_{2}$ in the initial stage of alteration. If this be the case, we suggest that the $\mathrm{fO}_{2}$ of the incoming fluid indirectly controlled sulfur activity in the fluid reacting with the minerals. In other words, this signifies that the capacity of the mineral assemblage to buffer the infiltrating fluid $\mathrm{fO}_{2}$ determined the $a \%$, and thereby the sulfide paragenesis (pyrrhotite, and/or pyrite, and/or arsenopyrite) in physical space, in chemical space and over geological time (see Lobato 1998). This is also a reflection of fluid to rock ratio.

In the presence of magnetite at Raposos for example, the infiltrating, reduced fluid is initially involved in accommodating the redox disequilibrium with this $\mathrm{Fe}^{37}$-bearing phase, via windespread growth of pyrrhotite. With buffering of fluid $f O_{2}, a_{\Sigma S}$ is relatively augmented influencing and facilitating the subsequent development of much less abundant pyrite. 
On the other hand, the presence of carbonaceous matter with no magnetite in the Cuiabá BIF may in part explain the predominance of pyrite (and rare pyrrhotite) during sulfidation. As shown by Toledo (1997), carbonaceous matter is oxidized and Fe-carbonates develop. Aggregates of pyrite ( \pm arsenopyrite) substitute carbonates (siderite and Mn-ankerite) in various pulses of fluid to rock interaction. Pyrrhotite, chalcopyrite and sphalerite are subordinate. The oxidation of carbonaceous matter in Cuiabá may have been related to the interaction with a fluid similar to that which reduced magnetite to produce sulfides and carbonate (Raposos). The presence of carbonate haloes separating carbonaceous matter from pyrite (Toledo 1997, Fig. 80) suggests that $\mathrm{JO}_{2}$ buffering might have given way to widespread carbonate development, and subsequent relative increase in $a_{\Sigma S}$. Under higher $a_{\Sigma S}$ conditions the Fe-carbonate to pyrite transformation occurred.

A parallel can be traced between Cuiabá and the carbonate-dominated, hydrothermal alteration at the Kerr-Addison Mine, Canada (Kishida and Kerrich 1987). The deposit lies in a fault zone, with host rocks to the north containing magnetite as opposed to the more reducing conditions to the south, indicated by the presence of graphite. Along the fault interface, interaction with the same fluid oxidized carbon and reduced $\mathrm{Fe}^{3+}$ of magnetite, both reactions producing $\mathrm{Fe}$ carbonates (ankerite and ferro-dolomite). The authors indicate that $\mathrm{X}_{\mathrm{C}} \mathrm{p}_{2}$, defined as $\mathrm{CO}_{2} /\left(\mathrm{CO}_{2}+\mathrm{H}_{2} \mathrm{O}+\mathrm{CH}_{4}\right)$, is also a function of $f \mathrm{O}_{2}$, which may be controlled by either the infiltrating fluid or by reaction with the wallrocks. The. $f \mathrm{O}_{2}$ of the incoming fluid then controlled the proportion of $\mathrm{CO}_{2}$ in the fluid in contact with graphite-bearing wallrocks (graphite oxidation). There is preferential gold concentration south of the fault, suggesting that its precipitation was controlled by the $f \mathrm{O}_{2}$ of the fluid.

Pyrrhotite development is also constrained by the tectonic regime. At the Raposos Mine, gold-bearing sulfide zones are preferentially associated respectively with $\mathrm{D}_{\mathrm{t}}$ and $\mathrm{D}_{2}$ structures of Vieira and Oliveira (1988). These zones are interpreted as resulting from different tectonic conditions by Vieira (1987b), with pyrrhotite forming in tensional zones, and pyrite + arsenopyrite in dilatational zones (Types- 1 and -2 mineralization styles, respectively) in different, time-unrelated deformational phases. Pyrrhotite also dominates shearzones in Cuiabá (Toledo 1997).

Our integrated observations suggest that such styles of sulfide enrichment were conditioned by the fluid evolutionary history and tectonic structures, but are not related to any specific timeframe.

From the borders of zones dominated by pyrrhotite (Type-1 mineralization style), fractures developed and advanced into BIF banding, where subhedral to anhedral pyrite and arsenopyrite grew (Type-2 mineralization style). However, the first few centimeters of such fractures are filled by pyrrhotite that is immediately followed by the former two sulfides. Streaks containing all three sulfides ( \pm chalcopyrite) can be cut by trails of similar composition, suggesting two to three similar pulses of fluid introduction. Ladeira (1988) also points out to the presence of pyrrhotite-filled fractures, and indicates that there are varying generations of the pair arsenopyrite + pyrite. Both minerals can be traced along $\mathrm{Sj}$ in deformed ("mylonitic") crystals, thus contemporaneous to pyrrhotite, and appear euhedral, post- $\mathrm{S}_{1}$

As already pointed out, the initial fluid was relatively reducing and its $\mathrm{fO}_{2}$ and $\mathrm{a}_{\mathrm{fs}}$ were controlled by the pyrite-pyrrhotite pair in the presence of arsenopyrite, hence slightly above the $\mathrm{CO}_{2}-\mathrm{CH}_{4}$ stability curve (Figure 1). In the $\mathrm{T}$ range estimated, the stability of pyrite and pyrrhotite is a function of $f \mathrm{O}_{2}$ and $a_{\Sigma S}$ (Meyer and Hemley 1969), and as already proposed mineral reactions must have acted at first to buffer

$\mathrm{fO}_{2}$

We suggest that the shear-controlled, pyrrhotite-dominant sulfidation style reflects not only variations in rock composition, but alse focused fluid-rock interaction, resulting in relatively narrow zones originally dominated by the mineralogical composition of pre-altered BIF. Interestingly, gold grade increases from the core of such mineralized, sulfide-rich, reflecting the highest fluid to rock ratio, to the borders of pyrrhotite orebodies.

Under high fluid pressure $\left(\mathrm{P}_{\text {fluid }}\right)$ conditions, chemical disequilibrium was extreme and the predominant sulfide was pyrrhotite. Field observations at the Morro da Glória Mine, for example, confirm that fracture development was enhanced with local brecciation of BIF. Fracturing results in lowering of $\mathrm{P}_{\text {fluid }}$ and in subsequent fluid to rock interaction over a much less restricted area.

With buffering of $\mathrm{fO}_{2}$, the evolved fluid must have attained higher $\mathrm{a}_{\mathrm{s} S}$, under conditions of lower fluid flow (lower $\mathrm{P}_{\text {fluid }}$ ). and hence lower fluid to rock ratio, and the nucleation of both pyrite and arsenopyrite followed.
As pointed out by Sibson (1990a), in lode-gold deposits veining appears to have developed during episodes of compressional or transpressional tectonism associated with steep, reverse or reverse-oblique shear zones. These act as $\mathrm{P}_{\text {fluid-activated valves, causing } \mathrm{P}_{\text {fluid }} \text { to cycle }}$ between pre-failure lithostatic and post-failure hydrostatic values in extreme cases. $\mathrm{P}_{\text {fluid }}$-activated valves control fluid to rock interaction (Cox et al. 1991). At elevated $\mathrm{P}_{\text {fluid, }}$ extension fractures propagate into the wallrock. Up to the point of failure, $\mathrm{P}_{\text {fluid }}$ in the fault and/or shear zone is higher than in the adjacent wallrocks, driving fluid out of this zone and promoting interaction with wallrocks. Following failure and valve breach, there is a decrease in $\mathrm{P}_{\text {fluid }}$ that is transiently lower than in the wallrocks. This causes reacted fluids to migrate back into the fault zone where they can mix with primary ore fluids and promote $\mathrm{Au}$ deposition.

Hydrothermal precipitation is enhanced by major $\mathrm{P}_{\text {fluid }}$ reduction. Because the pressure drops from extreme fault-valve behavior are potentially so large, phase separation of $\mathrm{CO}_{2}$ becomes likely in a mixed $\mathrm{CO}_{2}-\mathrm{H}_{2} \mathrm{O}$ fluid, even at considerable depth (Sibson 1990b). Phase separation plays a very important role in gold precipitation (Phillips and Powell 1992).

Variations in the mineral composition of some hydrothermal phases with depht are registrered in various mines. They can also be alternatively explained as reflecting fluid evolution due to variations in volatile fugacities. This could be the case regarding pyrrhotite increase in Morro Velho and São Bento Mines. Vieira (1986) interprets this variation because of a temperature increase. He correlates the increase in pyrrhotite ( \pm biotite) with conditions prevailing in mineralizations close to Pitangui (Pontal and Faina), located at the northwestern outskirts of the $Q F$. In these deposits the presence of biotite together with garnet, pyrrhotite and other sulfides indicates higher temperature than that characteristic of the gold deposits described by Lobato et al. (1998b, the present volume). In the case of the São Bento Mine, the increase in pyrrhotite with depth has also been interpreted as resulting from a T augmentation (Marchetto 1997).

A similar trend in the sulfide and phyllosilicate mineral compositions is described for the alteration at the Hollinger-Mclntyre and Sigma deposits, in Canada (Hodgson 1993). This change alongside with other mineralogical variations is consistent with increasing $\mathrm{T}$ and/or decreasing volatile fugacities in the hydrothermal fluid with depth.

Consistenly, studies of fluid inclusions (Robert and Kelly 1987) and of oxygen isotopes (Kishida and Kerrich 1987) show no systematic variation in $\mathrm{T}$ with depth, corroborating the notion that the alteration is roughly isothermal (McCuaig and Kerrich 1994). Vertical zonation of wallrock alteration is not common in individual lode-gold deposits, though reported (see Groves 1993). Most lode-gold deposits are characterized by alteration assemblages commensurate with the ambient metamorphic P-T conditions (Clark et al. 1989). Pyrite \pm arsenopyrite \pm pyrrhotite is typical of the greenschist to low-amphibolite facies conditions. In higher $\mathrm{T}$ deposits lõellingite, magnetite and ilmenite appear, plagioclase is oligoclase-andesine and amphibole develops.

In the absence of det alled T calculations for varying depth levels in the $Q F$ gold mines, an alternative explanation lies with the evolution in fluid composition. We suggest that the changes in mineralogical composition with depth, exemplified at Morro Velho and São Bento, be related to changes in fluid fugacity (buffering). As depicted in Figure 1, pyrrhotite formation in preference to pyrite is a function of $\mathrm{fO}_{2}$ and/or a $\mathrm{as}_{\mathrm{s}}$. Meyer and Hemley (1969) indicate that the conventional connotation of high $\mathrm{T}$ with pyrrhotite is inconclusive since chemical factors, as well as $\mathrm{T}$, are important controls.

These fluid fugacity variations, reflected in the depth-varying pyrite to pyrrhotite modal ratios, are expected to affect gold grades. Insufficient information is available at this stage either to constrain these critical parameters or to adequately predict grade behavior and its correlation with such parameters. However, these data would have immediate exploration applications.

Regardless of overall $f \mathrm{O}_{2}$ and $\mathrm{a}_{\Sigma \mathrm{S}}$ buffering, during stages of hydrothermal alteration characteristic of unbuffered conditions, such parameters varied slightly, particularly along the contacts between alteration zones. For instance, the nucleation of $\mathrm{Fe}^{2+}$-bearing phases (sulfides, carbonates) must have forced. $f \mathrm{O}_{2}$ to somewhat higher values. On the other hand, in the advanced stages of hydrothermal alteration at Jucá Vieira (Pereira 1996), chlorite is oxidized to form pyrite (clinochlore/chamosite $+12 \mathrm{H}_{2} \mathrm{~S}+\mathrm{O}_{2}=6$ pyrite $+4 \mathrm{SiO}_{2}+16 \mathrm{H}_{2} \mathrm{O}$; Phillips 1985). If unbuffered, this transformation can lead to chlorite disappearance, hence evolving fluids of slightly lower $\mathrm{fO}_{2}$ conditions. Variations in $\mathrm{fO}_{2}$ and the precipitation of sulfides have a strong 


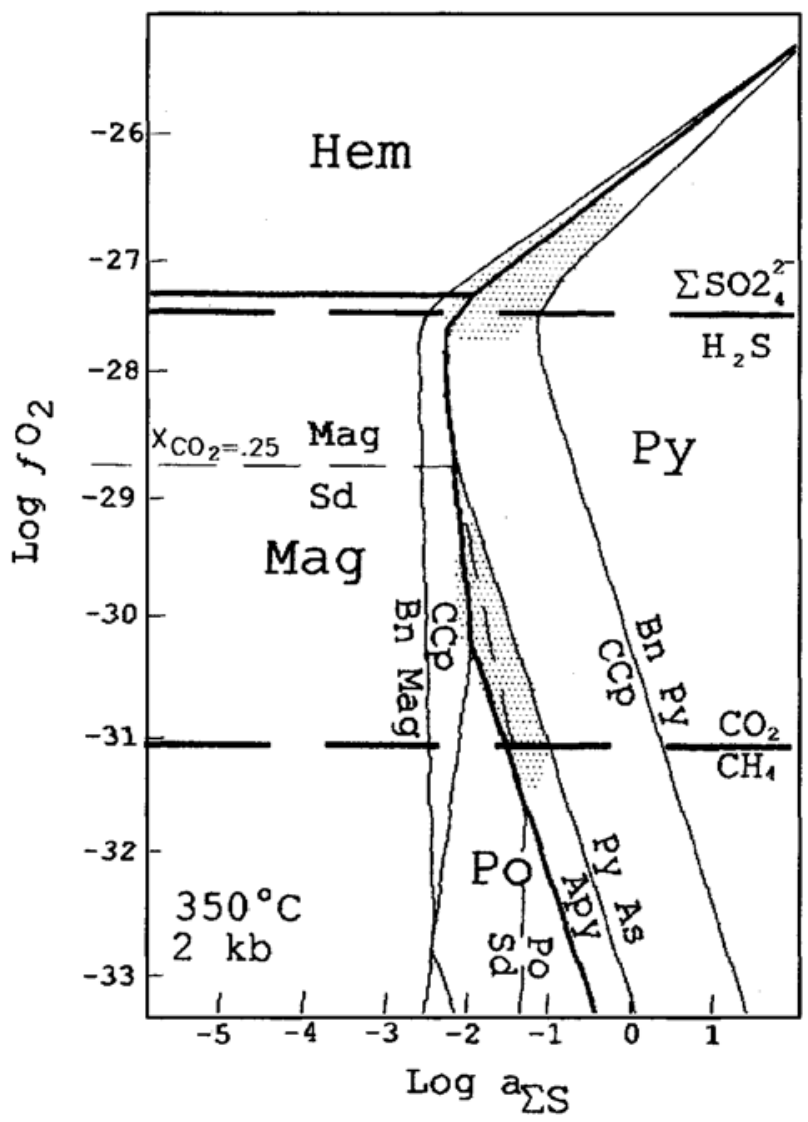

Figure l-After Mikucki and Ridley (1993; Fig. 5). Log $\mathrm{fO}_{2}$ versus ais diagram for $350^{\circ} \mathrm{C}, 2 \mathrm{~kb}$ and $\Sigma \mathrm{SO}^{*}=10^{3}$ aso $42 \sim$ Patterned areas are likely $\mathrm{fO}_{2}$ and azs conditions for typical sub-amphibolite fades gold deposits. Stability boundaries for Fe-sulfide and Fe-oxide phases are shown as heavy solid lines: light solid lines and dashed lines show reaction boundaries for $\mathrm{Cu}$ - and As-bearing phases, and carbonate phases (at Xco2 $=0.25$ ), respectively. Heavy dashed lines are important aqueous redox buffers. Ore fluid conditions for 'reduced' greenschist fades lode-gold deposits are limited by the assemblage pyrite \pm pyrrhotite \pm arsenopyrite \pm siderite, and fluid inclusion constraints that suggest $\mathrm{CO} / \mathrm{CH} 4>1.0$. Fluids associated with mesothermal gold deposits of the $Q F$, described by Lobato et al. (1998b, the present volume), belong to this group. Those for 'oxidized' greenschist-fades deposits are limited by pyrrhotite-chalcopyrite \pm hematite \pm magnetite stability, which together with isotopic evidence suggest combined sulfate species exceed sulfide contents. As = arsenic met al; Apy $=$ arsenopyrite; $B n=$ bornite; $C c p=$ chalcopyrite; Hem = hematite; Mag - magnetite; $P o=$ pyrrhotite; $P y=$ pyrite; $S d=$ siderite .

influence on gold deposition from reduced gold-bearing, sulfur complexes (see below).

pH CONDITIONS AND IONIC COMPONENTS Ore-fluid pH can be estimated taking into account the alteration involving white micas \pm albite. For likely low ore fluid salinities, $\mathrm{pH}$ values thus vary over the restricted range of 5.2 to 6.2 (Figure 3), that is from near-neutral to slightly alkaline in nature (neutral $\mathrm{pH}=5.2$ at $350^{\circ} \mathrm{C}, 2 \mathrm{~kb}$ ).

Common components in ore-forming fluids are $\mathrm{Na}^{+}, \mathrm{K}^{+}$and $\mathrm{Ca}^{2}+$. Fluid composition can be inferred by observation of Figure 3, at varying $\mathrm{pH}$ values. Activities of $\mathrm{Na}^{+}$are roughly one order of magnitude greater than those of $\mathrm{K}+$, supporting inference from fluid inclusion studies that $\mathrm{Na}^{+}$is the dominant cation (Mikucki and Ridley 1993).

$p H$ evolution in $Q F$ gold-mineralizing deposits In all deposits described by Lobato et al. (1998b, the present volume), development of both $\mathrm{K} / \mathrm{Na}$-mica and varying amounts of albitic plagioclase, in the presence of carbonates, must have reflected small variations in $\mathrm{X}_{\mathrm{C} 02}$, and in the activities of $\mathrm{K}^{+} / \mathrm{H}^{+}$and $\mathrm{Na}^{+} / \mathrm{H}^{+}$, particularly in the case of metamorphosed mafic and ultramafic rocks. This infers a near-neutral

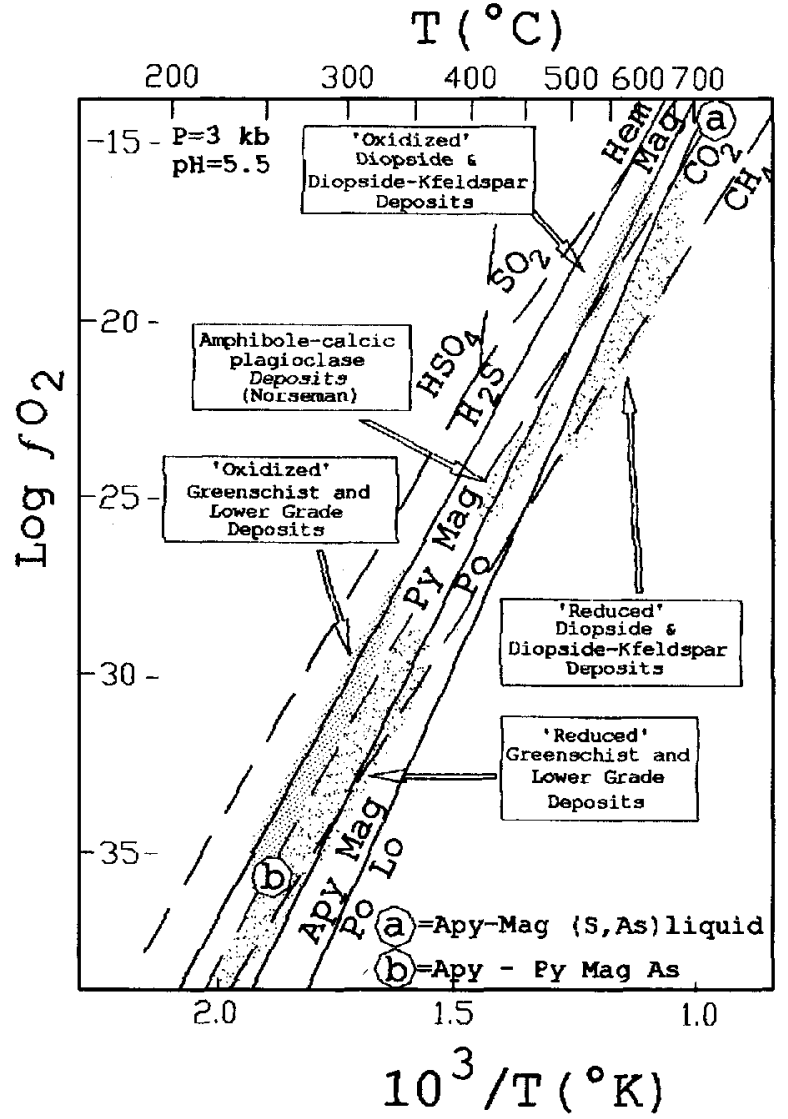

Figure 2 - After Mikucki and Ridley (1993; Fig. 7). Summary diagram of the fields of oxidation state and temperature inferred for Archean lode-gold deposit ore fluids, pertaining to deposits in the greenschist and sub-amphibolite fades, embodying the deposits described by Lobato et al. (1998b, the present volume). Shown for comparison are reaction boundaries for solid-solid buffer assemblages (heavy solid lines) and buffer curves for aqueous carbon and sulfur species (heavy dashed lines). The thin dashed line delineates the upper stability of arsenopyrite through the reaction as labeled. Ranges for fU2 were calculated from mineral assemblages, mineral compositional data and $P$-T estimates reported for deposits in the greenschist and sub-amphibolite fades (see Mikucki and Ridley 1993 for further det alls).

to slightly alkaline original fluid. Because these reactions release $\mathrm{H}+$, near-neutral to slightly acid conditions may have prevailed in the more advanced stages of hydrothermal alteration.

At Jucá Vieira, reactions involving the formation of paragonite + quartz and paragonite + ankerite from chlorite are cation consuming, with $\mathrm{H}^{+}$-release. $\mathrm{H}^{+}$is also released from the paragonite to albite transformation. These reactions suggest that under fluid-dominated conditions a near-acid fluid may in fact have evolved (Pereira 1996).

In metamafic rocks at Raposos, the replacement of metamorphic albite by sericite suggests interaction with a $\mathrm{CO}_{2}+\mathrm{K}^{+}$-rich fluid, evolving into a $\mathrm{H}_{2} \mathrm{O}+\mathrm{Na}^{+}$fluid responsible for hydrothermal albite generation. Chlorite + calcite are replaced by sericite $+\mathrm{Mg}$-siderite + quartz, suggesting reaction with a $\mathrm{CO}_{2}+\mathrm{K}^{+}$-rich fluid and $\mathrm{H}+$ release. In the advanced stage of hydrothermal alteration of meta-ultramafic rocks, the replacement of calcite + quartz by ankerite + albite $( \pm$ $\mathrm{Mg}$-Fe-chlorite) can be envisaged through the reaction with a $\mathrm{CO}_{2}+$ $\mathrm{Na}^{+}$fluid and $\mathrm{H}^{+}$release (Junqueira 1997).

In Santana, the replacement of biotite by either chlorite or muscovite involves hydrolysis reactions with $\mathrm{K}^{+}$release. Chlorite, on the other hand, consumes $\mathrm{K}^{+}$to give way to muscovite, again suggesting slight fluctuations in the fluid $\mathrm{K}^{+} / \mathrm{H}^{+}$.

Carbonate alteration is widespread in all deposits. As in the case of deposits discussed elsewhere (Kishida and Kerrich 1987), carbonate precipitation reactions lead to fluid acidification. Variations in $\mathrm{pH}$ are however minimal considering that hydrolysis reactions involving hy- 


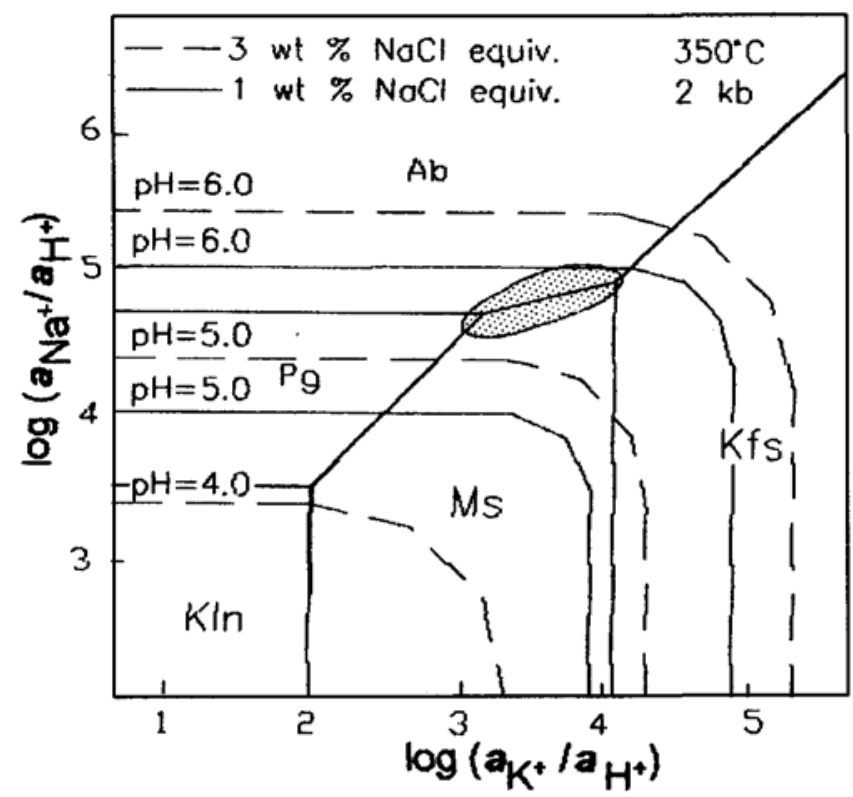

Figure 3 - After Mikucki and Ridley (1993; Fig. 3). Stability relationships/or Na-K aluminosilicates as a function of fluid composition at $350^{\circ} \mathrm{C}$ and $2 \mathrm{~kb}$. The shaded area is the field of fluid compositions for most sub-amphibolite fades Archean gold-ore fluids, including the deposits describedin this paper. pH contours arefor $3 \%$ (long-dashed lines) and 1\% (short-dashed lines) Nad. Data from Bowers et al. (1984) and Shock and Helgeson (1988). Ab = albite; $K f_{s}=K$-feldspar; Kin = kaolinite; $P g=$ paragonite .

drothermal gold ore-fluids and wallrocks (feldspar to sericite) provide a convenient and likely sink (neutralizer) for the excess $\mathrm{H}^{+}$produced by acid dissociation and carbonate precipitation.

The increase in pyrrhotite with depth at the Morro Velho Mine is also marked by the appearance of biotite and reduction in the amount of chlorite in hydrothermally altered rocks surrounding ore (Vieira 1988). Biotite to chlorite transformation at $300^{\circ} \mathrm{C}$ is a function of variations in the $\mathrm{K}^{+} / \mathrm{H}_{+}$and $\left(\mathrm{Mg}^{2+}, \mathrm{Fe}^{2+}\right) /\left(\mathrm{H}^{+}\right)^{2}$ activities of the fluid (Beane 1994). Alternatively to the temperature increase at depth, discussed by some authors (see also Lobato et al. 1998b, the present volume, we suggest that biotite development at the expense of chlorite may reflect increase in these ratios in the fluid, again owing to fluid to rock interaction. Interestingly, whereas pyrite alteration is more common where serialization occurs, pyrrhotite predominates in zones of chlorite alteration indicating a pattern of moderately high $\mathrm{K}^{+} / \mathrm{H}^{+}$conditions for the latter. In fact, Mikucki and Ridley (1993) mention a $\mathrm{pH}$ range of 5.8 to 6.8 for fluids responsible for the biotite-ankerite hydrothermal association at Kambalda (Australia).

Fluid Evolution and Implications for Gold Transport and Deposition The close association between gold mineralization and sulfides in all deposits suggests that reduced sulfur complexes were the predominant transport mechanism. Microtextural studies indicate that gold deposition occurred simultaneously with sulfide precipitation due to fluid-wallrock sulfidation reactions.

Studies of gold transport in ore-depositing environments have shown that sulfide complexes of gold are of major importance in the near-neutral region of $\mathrm{pH}$, atTs no higher than $\sim 300^{\circ} \mathrm{C}$ (Seward 1993). Gold solubility as a reduced sulfur complex (Au(HS)-2) is also affected by variations in $f \mathrm{O}_{2}$ and $\%$, particularly by increasing fluid $\mathrm{fO}_{2}$ and decreasing $a_{\mathfrak{L}}$. Thioarsenide complexes are also important (Romberger 1986). Saturation of gold in the fluid decreases in response to lower T, lower $\mathrm{fO}_{2}$ and particularly lower sulfur activity until the fluid becomes gold-saturated. Only once gold-saturation is approached, will extensive gold deposition proceed (Phillips and Powell 1992).

Gold deposition is a function of physico-chemical changes in the fluid that will lead to removal of gold from solution by destabilizing gold complexes. This can be achieved by variations in the fluid due to (1) cooling; (2) oxidation, (3) reduction, (4) pH variation, (5) lowering $\mathrm{a}_{\Sigma \mathrm{S}}$, (6) lowering of pressure, with phase separation, (7) solution mixing, (8) wallrock alteration. Interplay of these factors may have played a role in gold deposition in the deposits described in the QF.
Evidence for cooling of the fluid is brought about by data from Alves (1995) for the São Bento Mine, with a variation from $\sim 300^{\circ} \mathrm{C}$ at $3.2 \mathrm{~kb}$ to $\sim 200^{\circ} \mathrm{C}$ at $1 \mathrm{~kb}$.

Slight variations in the fluid, $\mathrm{fO}_{2}$ are particularly important in the case of Fe-bearing host rocks (BIF and lapa seca). Sulfidation of Fe-rich wallrocks has been demonstrated as an efficient gold deposition mechanism, mainly in the case of many large replacement orebodies like those hosted by BIF and lapa seca (see Phillips et al. 1984, McCuaig and Kerrich 1994 for discussion). Not only do sulfides replace original carbonate and magnetite, but they also replace advanced-stage carbonates, suggesting multiple pulses of sulfide nucleation. The oxidation of sulfur $\mathrm{S}^{2}$ - to form pyrite $\left(\mathrm{S}^{1-}\right)$ provides a driving force to reduce aurous complexes of gold. Pyrrhotite formation can also reduce $\mathrm{Au}^{+}$but tends to be less effective.

Since intense $\mathrm{K}^{+}$and $\mathrm{CO}_{2}$ metasomatism is plentiful, some $\mathrm{pH}$ reduction has been deduced. The reduction in $\mathrm{pH}$ strongly enhances gold precipitation. $\mathrm{pH}$ influence seems to have been particularly important in the case of the Jucá Vieira (Pereira 1996) and Santana gold deposits. The evolution to a near-acid fluid resulting from widespread K/Na-mica development at Jucá Vieira may have been in part responsible for gold precipitation.

CONCLUSIONS The first part of this paper reviews the state of the art relating to hydrothermal alteration associated with mesothermal, lode-gold deposits, particularly those hosted by rocks of Archean greenstone belts holding mineral assemblages of the sub-amphibolite and greenschist facies of metamorphism. The most critical points embrace the following conclusions:

1 - Structurally hosted, mesothermal, lode-gold deposits in metamorphic terranes constitute a single, coherent group of epigenetic precious met al deposits;

2 - The study of hydrothermal alteration associated with Archean, lode-gold mineralizations focused on the sub-amphibolite to greenschist facies group of deposits. These studies show that a central core of Fe-carbonate (ankerite) grades out into fringes rich in calcite and chlorite. Ore zones normally have micas, albite and less commonly $\mathrm{K}$-feldspar. Quartz veining and silicification are variably developed, together with sulfidation and tourmaline that may be locally abundant;

3 - Deposits are typically hosted by mafic volcanic rocks and by banded iron-formation (BIF). Gold resides within sulfides (mainly pyrite \pm pyrrhotite \pm arsenopyrite) that replace iron minerals in the altered wallrock immediately adjacent to quartz veins;

4 - Differences in alteration assemblages from one deposit to another reflect different fluid compositions and primary rock types;

5 - Inner (proximal) zones reflect fluid-dominated (unbuffered), metasomatic reactions. Zones distant from veins reflect a decreasing gradient of fluid to rock ratio. They represent progressive infiltration of the fluid into the wallrock:

6 - Gold mineralizing fluids were $\mathrm{CO}_{2}-\mathrm{H}_{2} \mathrm{O}$-rich, of relatively low salinity around 3-6 vol. \% NaCI equivalent, and moderate density $\left(0.3-0.9 \mathrm{~g} / \mathrm{cm}^{3}\right)$. They were near neutral to slightly alkaline and mainly reducing, with small concentrations of $\mathrm{CH}_{4}>$ although oxidized fluids have also been recorded;

7 - Typical temperature and pressure were 300 to $350^{\circ} \mathrm{C}$ and 1 to 3 $\mathrm{kb}$, respectively. Minimum gold depositional conditions were 200 $400^{\circ} \mathrm{C}$ (mainly $250-350^{\circ} \mathrm{C}$ ) and $0.5-4.5 \mathrm{~kb}$ (mainly $0.8-3 \mathrm{~kb}$ );

8 - Estimates of $\mathrm{X}_{\mathrm{C} 02}$ of the initial ore fluid indicate a range of $0.05-0.25$, increasing with the advancement of alteration. $\mathrm{CO}_{2}$ gradients controlled alteration-zoning patterns under isothermal conditions;

9 - $\mathrm{Log} \mathrm{fO}_{2}$ was in the range of $0.5-3$ above the $\mathrm{CO}_{2}-\mathrm{CH}_{4}$ stability curve. Total sulfur concentration was in the range of $\sim 10$ to $10^{-3.5} \mathrm{~m}_{\Sigma \mathrm{s}}$;

10 - The $\mathrm{pH}$ of solutions was near neutral to slightly alkaline.

Descriptions of mineral assemblages in a series of deposits associated with rocks of the Nova Lima Group, Quadrilátero Ferrífero region of Minas Gerais, Brazil, are presented by Lobato et al. (1998b, the present volume). In the second part of the present paper, the hydrothermal alteration of such deposits is scrutinized. To achieve this objective published det alled information on fluid composition for other similar deposits and fluid inclusion data for the QF are combined. It has been shown that:

1 - For metamafic and meta-ultramafic rocks, alteration assemblages of the incipient stage of alteration vary according to changes in $\mathrm{X}_{\mathrm{C} 02}$ under isothermal conditions. If albite and/or white mica is involved, reactions are also dependent on $a_{(K+N a+) \text {; }}$

2 - Stages of advanced hydrothermalism, with carbonate-white mica alteration depend on $\mathrm{X}_{\mathrm{CO} 2}$, and activities of $\mathrm{K}^{+} / \mathrm{H}^{+}$and $\mathrm{Na}^{+} / \mathrm{H}^{+}$;

3 - The least-altered chlorite-dominant, and the most-altered carbonate-dominant alteration assemblages suggest a shift from a pre- 
dominantly predominantly $\mathrm{H}_{2} \mathrm{O}$-rich fluid in the incipient stage (chloritization) to a higher $\mathrm{CO}_{2}: \mathrm{H}_{2} \mathrm{O}$ ratio in the most advanced stages of hydrothermal alteration;

4 - In metamafic rocks, slight variations in $\mathrm{fO}_{2}$ and $\mathrm{pH}$ are demonstrated by mineral reactions. An initially reducing fluid was buffered to somewhat higher $f \mathrm{O}_{2}$ via reaction with original metamorphic epidote, and later to lower $f \mathrm{O}_{2}$ due to chlorite oxidation. An initially near-neutral to slightly alkaline fluid evolves to slightly acid conditions due to reactions that release $\mathrm{H}^{+}$;

5 - The progressive hydrothermal alteration of the Al-poor BIF shows that original siderite and magnetite are recurrently replaced by ankerite and sulfides. Chlorite appears when pyrrhotite appears. Some albite and muscovite are present in the advanced stage (gold-rich ore). This indicates that buffering of fluid $f_{2}, \mathrm{a}_{\Sigma \mathrm{S}}$ and $\mathrm{X}_{\mathrm{C} 02}$ controlled BIF alteration, that was much less sensitive to activities of $\mathrm{K}+/ \mathrm{H}+$ and $\mathrm{Na}+/ \mathrm{H}+$

6 - Based on mineral transformations, it is concluded that ore fluid $\mathrm{X}_{\mathrm{C} 22}$, ass $f \mathrm{O}_{2}$ and $\mathrm{pH}$ values are similar to those postulated for deposits elsewhere. The assemblage pyrite \pm arsenopyrite \pm pyrrhotite formed from a reducing fluid with $f \mathrm{O}_{2}$ above or near that of the $\mathrm{CO}_{2}-\mathrm{CH}_{4}$ redox buffer;

7 - Significant amounts of sulfur were added during BIF alteration. Considering the relatively sulfur-rich, reducing nature of the original fluid, interaction with magnetite and siderite in the incipient stage of alteration must have provided the conditions necessary to buffer the incoming fluid $f \mathrm{O}_{2}$. Hence, the capacity of the mineral assemblage to buffer the infiltrating fluid $f \mathrm{O}_{2}$ determined 1) the $\mathrm{a}_{\Sigma \mathrm{S}}\left(\right.$ and $\mathrm{X}_{\mathrm{C} 02}$ ) in the fluid reacting with the minerals, and thereby 2 ) the sulfide paragenesis in physical space, in chemical space and over geological time.

8 - Variations in $a_{\Sigma S}$ can also be deduced from the gold-associated alteration in BIF. Shear zones are occupied mainly by pyrrhotite, whereas pyrite + arsenopyrite occur as discrete bedding-replacement zones in BIF. These variations can also be interpreted as a result of varying $\mathrm{P}_{\text {fluid }}$ conditions of a somewhat reducing, sulfur-rich fluid;
9 - The incipient (buffered) and more advanced (unbuffered) stages of alteration can be interpreted in terms of gradual evolution of the composition of a relatively uniform, external fluid through interaction with wallrocks, thus reflecting varying fluid to rock ratios;

10 - The information available indicates that the hydrothermal alteration and gold precipitation were roughly isothermal, in keeping with temperature and pressure calculations of deposits in the greenschist to sub-amphibolite metamorphic facies in other parts of the world;

11 - Suggested variations in $f O_{2}, \mathrm{pH}$ and $\mathrm{a}_{\mathrm{ss}}$ during fluid buffering probably played an important role in gold deposition.

Acknowledgements In this review paper we have attempted to distil some of the essence of the knowledge on hydrothermal alteration and gold in the Quadrilátero Femfero. This in no way does justice to the huge and growing body of literature on the mineral deposits in the region. Sincere thanks are due to L.C. Ribeiro-Rodrigues, L.M.M. Pereira, M. Menezes, P.A. Junqueira, S.L. Martins Pereira, whose data and ideas heavily influenced our own conclusions. We wish to thank Mineração Morro Velho and Eldorado Corporation for their support, for granting permission to collect samples and for sharing data with us. CPRM-Serviço Geológico do Brasil, COMIG and colleagues at CPMTC-IGC are acknowledged for their valuable co-operation. Discussions with Eduardo Simões and Eduardo A. Ladeira, and many other geologists and geology students, who have worked on gold deposits in the $\mathrm{QF}$, provided a wealth of stimulating ideas over the years. The senior author is indebted to Franciscus J. Baars for his patient discussions and enlightening comments which enormously improved the earlier draft manuscript. D.L. de Souza Bernardino dispensed great help in putting together the reference list. S.R. da Silva helped in the study of thin sections of the Raposos Mine. João H. Laurenti drafted most of the figures. Much of the results of our research have benefited from continuing financial support from CAPES, FINEP, FAPEMIG and CNPq in the form of bursaries and project resources.

\section{References}

Abreu, G.C. 1995. Geologia e Met alogênese do Ouro da Mina do Pari, NE do Ouadrilátero Ferrifero-MG. Inst. de Geociências, Universidade de São Paulo, São Paulo, M. Sc. Thesis, $163 \mathrm{p}$.

Almeida, F.F.M.; Hasui, Y. (eds.) 1984. O Pré-Cambriano do Brasil. São Paulo, Edgar Blücher Ltda., $378 \mathrm{p}$

Alves, J. V. 1995. Estudo das Inclusões Fluidas em Veios de Quartzo da Mina de Ouro de São Bento, Santa Bárbara, MG. Inst. de Geociências, Universidade Federal de Minas Gerais, Belo Horizonte, M. Sc. Thesis, $99 \mathrm{p}$.

Alves, J.V.; Fuzikawa, K; Pimenta, M.A.; Lobato, L.M. 1992. Microtermometria e espectroscopia microraman de inclusões fluidas em quartzo de veio aurífero da Mina de São Bento (Quadrilátero Ferrífero), MG: Resultados preliminares. In: SBG, Congr. Brás. Geol., 37, São Paulo, Anais, 2: 9-10

Alves, J.V.; Fuzikawa, K.; Lobato, L.M.; Dantas, M.S.S.; Cornelissen, M.G. 1997. Determinação quantitativa, por espectroscopia microraman, dos componentes da fase carbônica das inclusões fluidas da Mina de Ouro de São Bento, Santa Bárbara, MG. Rev. Esc. Minas, Ouro Preto, 50(2): 51-54

Appleyard, E.C.; Guba, J. 1991. Preface. In: E.C. Appleyard; J. Guha (eds.) A Special Issue on Applications of H\drothermal Alteration Studies to Mineral Exploration USA, Econ. Geol. Publishing Co., 461-465 (Econ. Geol. 88/3)

Beane, R.E. 1994. A graphic view of hydrothermal mineral stability relations. In: D.R. Lenz (ed.) Alteration and Alteration Processes Associated with Ore-Forming Systems, St. John's, Canada, Geol. Assoc. of Canada, 1-30 (Short Course Notes 11)

Bohlke, J.K. 1989. Comparison of metasomatic reactions between a common CCh-rich vein fluid and diverse wall rocks: Intensive variables, mass transfers, and $\mathrm{Au}$ mineralization at Alleghany, California. Econ. Geol., 84(2): 291-327

Boyle, R.W. 1991. Auriferous Archean greenstone-sedimentary belts. In: B.J. Skinner (ed.) Historical Perspectives of Genetic Concepts and Case Histories of Famous Discoveries. New Haven, USA, Econ. Geol. Publishing Co., 164-191 (Econ. Geol. Monograph 8)

Borba, R.P. 1998. MagmatismoÁcido e sua Relação com a Mineralização Aurífera de Bico de Pedra, Greenstone Belt Rio das Velhas, Quadrilátero Ferrifero, Minas Gerais, Brasil. Inst. Geociências, Universidade Estadual de Campinas, Campinas, M. Sc. Thesis, $162 \mathrm{p}$.

Bowers, T.S.; Jackson, K.J.; Helgeson, H.C. 1984. Equilibrium Activity Diagrams for Coexisting Minerals and Aqueous Solutions at Pressures and Temperatures to $5 \mathrm{~kb}$ and $60 Q^{\circ} \mathrm{C}$. New York, Springer Verlag, $397 \mathrm{p}$.

Bursnall, J.T. (ed.) 1989. Mineralization and Shear Zones. St. John's, Canada, Geological Assoc. of Canada, 300 p. (Short Course Notes 6)

Clark, M.E.; Carmichael, D.M.; Hodgson, C.J.; Fu, M. 1989. Wall-Rock alteration, Victory gold mine, Kambalda, Western Australia: Processes and P-T-Xco2 conditions of metasomatism. In: R.R. Keays; W.R.H. Ramsey; D.I. Groves (eds.) The Geology of Gold Deposits: The Perspectives In 1988. New Haven, USA, Econ. Geol. Publishing Co., 445-459 (Econ. Geol. Monograph 6)

Colvine, A.C.; Fyon, A.J.; Heather, K.B.; Marmont, S.; Smith, P.M.; Troop, D.G. 1988. Archean Lode Gold Deposits in Ontario. Toronto, Canadá, Ontario Geol. Surv., 136 p. (Miscellaneous Paper 139)
Colvine, A.C.; Andrews, A.J.; Cherry, M.E.; Durocher, M.E.; Fyon, A.J.; Lavigne, M.J.; MacDonald, A.J.; Marmont, S.; Poulsen, K.H.; Springer, J.S.; Troop, D.G. 1984. An Integrated Model for the Origin of Archean Lode Gold Deposits. Ontario Geol. Survey, 98 p. (Open File Report 5524)

Condie, K.C. 1981. Archean Greenstone Belts. Amsterdan, Elsevier, 434 p. (Development In Precambrian Geology 3)

Cox, S.F.; Etheridge, M.A.; Wall, V.J. 1990. Fluid pressure regimes and fluid dynamics during deformation of low grade metamorphic terrenes implications for the genesis of mesothermal gold deposits. In: F. Robert; P.A. Sheahan; S.B. Green (eds.) Greenstone Gold and Crustal Evolution. St. John's, Canada, Geol. Assoc. Canada, 46-53 (NUNA Conference Volume)

De Ronde, C.E.J.; Der. Channer, D.M.; Spooner, E.T.C. 1997. Archean fluids. In: M. De Wit; L.D. Ashwal (eds.) Greenstone Belts. Oxford, England, Clarendon Press, 309-335 (Oxford Monographs on Geology and Geophysics 35)

DeWitt, Ed; Landis, G.P.; Zartman, R.E.; Garayp, E.; Martins Pereira, S.L.; Prado, M.G.B.; Vieira, F.W.R.; Thorman, C.H. 1994. Isotopic and fluid inclusion data on the age and origin of the São Bento and Morro Velho Gold Deposits, Minas Gerais, Brazil In: C.H Thorman; D.E. Lane (eds.). United States Geol. Sur. Research on Mineral Deposits. Part A: Programs and Abstracts, 9th V.E. McKelvey Forum on Energy and Mineral Resources, 27-29 (Circular 1103-A)

Dorr II, J.V.N. 1969. Physiographic, Stratigraphic and Structural Development of the Quadrilátero Ferrifero Minas Gerais. Washington, United States Geol. Sur., 110 p. (Prof. Paper 641-A)

Duarte, B.P. 1991. Contribuição ao Estudo da Geologia do Corpo de Minério Fundão do Depósito Aurifero de Passagem, Mariana, MG. Inst. de Geociências, Universidade Federal do Rio de Janeiro, Rio de Janeiro, M.Sc. Thesis $175 \mathrm{p}$.

Dubé, B.; Guha, J.; Rochleau, M. 1987. Alteration patterns related to gold mineralization and their relation to CÓ2-H2O ratios. Mineralogy Petrology, 37: 267-291

Fleischer, R.; Routhier, P. 1973. The consanguineous origin of a tourmaline-bearing gold deposit: Passagem de Mariana, Brazil. Econ. Geol, 68(1): 11-22

Fortes, P.T.F.O.; Gonçalves, F.T.T.; Takaki, T. 1994. Estudo preliminar de isótopos estáveis de $\mathrm{C}$ em rochas carbonosas de greenstone belts arqueanos brasileiros. In: SBG, Cong. Bras. Geol., 38, Camboriú, Anais, 3: 139-140

Fyfe, W.S.; Price, N.J.; Thompson, A.B. 1978. Fluids in the Earth's Crust. Amsterdam, Elsevier, 383 p. (Development In Geochemistry 1)

Galbiatti, H.F. 1999. Natureza e Controle Estrutural da Mneralização Aurífera (Jacutingas) na Mina do Canê, Itabira, MG. Escola de Minas, Universidade Federal de Ouro Preto. M.Sc. Thesis, $150 \mathrm{p}$.

Godoy, M.L.S. 1994. Evolução Tectono-Metamórfica da Mineralização Aurífera de Raposos $(M G)$. Inst. de Geociências e Ciências Exatas, Universidade Estadual Paulista, Rio Claro, M. Sc. Thesis, 98 p.

Godoy, M.A.M. 1995. Caracterização Mineralógica do Minério, Concentrado e Rejeito da Flotação da Mina São Bento (MG). Inst. de Geociências, Universidade de Brasília, Brasília, M. Sc. Thesis, 204 p.

Groves, D.I. 1993. The crustal continuum for late-Archean lode-gold deposits of the Yilgarn Block, Western Australia. In: R. Kerrich (ed.) Western Australian Gold Deposits. Berlin, Germany, Springer-Verlag, 366-374 (Mineralium Deposita 28/6) 
Groves, D.I.; Foster, R.P. 1993. Archean lode gold deposits. In: R.P. Foster (ed.) Gold Met allogeny and Exploration. New York, Chapman \& Hall, 63-103

Guha, J.; Lu, H.Z.; Dubé, B.; Robert, F.; Gagnon, M. 1991. Fluid characteristics of vein and altered wall rock. In: Archean Mesothermal Gold Deposits. Econ. Geol, 88(3): 667-684

Henley, R.W.; Truesdell, A.H.; Barton Jr., P.B.; Whitney J.A. (eds.) 1984. Fluid-Mineral Equilibria in Hydrothermal Systems. El Paso, U.S.A. Soc. of Econ. Geologists, 267 p. (Reviews in Economic Geology 1)

Herrington, R.J.; Evans, D.M.; Buchanan, D.L. 1997. Met allogenenic aspects. In: M.J. De Wit; L.D. Ashwal (eds.) Greenstone Belts. Oxford, England, Clarendon Press, 177-219 (Oxford Monographs on Geology and Geophysics 35)

Hodgson, C.J. 1993. Mesothermal lode-gold deposits. In: R.V. Kirkham; W.D. Sinclair; R.I. Thorpe; J.M. Duke (eds.). Mineral Deposit Modeling. St. John's, Canada, Geol. Assoc. Canada, 635-678 (Special Paper 40)

Junqueira, P. A. 1997. Geologia do Depósito de Ouro da Mina de Raposos, Quadrilátero Ferrifero, com Ênfase na Alteração Hidrotermal. Inst. Geociências, Universidade Federal de Minas Gerais, Belo Horizonte, M. Sc. Thesis, 130 p.

Kerrich, R. 1990. Mesothermal gold deposits: A critique of genetic hypothesis. In: F. Robert; P. A. Sheahan; S.B. Green (eds.), Greenstone Gold and Crustal Evolution In: F. Robert; P.A. Sheahan; S.B. Green (eds.) Greenstone Gold and Crustal Evolution. St. John's, Canada, Geol. Assoc. Canada, 13-31 (NUNA Conference Volume)

Kerrich, R. 1993a (ed.). Western Australian Gold Deposits. Berlin, Germany, Springer-Verlag, 502 p. (Mineralium Deposita 28/6)

Kerrich, R. 1993b. Perspectives on genetic models for lode gold deposits. In: R. Kerrich (ed.) Western Australian Gold Deposits. Berlin, Germany, Springer-Verlag, 362-365 (Mineralium Deposita 28/6)

Kerswill, J.A. 1993. Models for iron-formation-hosted gold deposits. In: R.V. Kirkham; W.D. Sinclair; R.I. Thorpe; J.M. Duke (eds.). Mineral Deposit Modeling. Newfoundland, Geol. Assoc. Canada, 171-199 (Special Paper 40).

Kishida, A.; Kerrich, R. 1987. Hydrothermal alteration, zoning and gold concentration at the Kerr-Addison Archean lode gold deposit, Kirkland Lake, Ontario. Econ. Geol., 82(3): $649-690$

Knopf, A. 1929. The Mother Lode System of California. Washington, United States Geological Survey, 88 p. (Professional Paper 157)

Ladeira, E. A. 1980. Met allogenesis of Gold at the Morro Velho Mine and in Nova Lima, Quadrilátero Ferrifero, Minas Gerais, Brazil. University of Western Ontario, London, Canada, Ph. D. Thesis, $272 \mathrm{p}$.

Ladeira, E. A. 1981. Geologia e Gênese do Ouro da Mina de Morro Velho e do Ditrito de Nova Lima, Quadrilátero Ferrífero Minas Gerais. Secr. Minas Energia, Simp. Mineralizações Auríferas no Estado da Bahia, 5

Ladeira, E. A. 1988. Met alogenia dos depósitos de ouro do Quadrilátero Ferrífero, Minas Gerais. In: C. Schobbenhaus; C.E.S. Coelho (eds.) Principais Depósitos Minerais do Brasil-Met als Básicos Não Ferrosos, Ouro e Alumínio. Brasília, DNPM/CVRD, 3(25): 301-375

Ladeira, E.A. 1991. Genesis of gold in Quadrilátero Ferrífero: a remarkable case of permanency, recycling and inheritance - a tribute to Djalma Guimarães, Pierre Routhier and Hans Ramberg. In: E.A. Ladeira (ed.) Proceedings of Brazil GOLD'91, the Economics, Geology, Geochemistry and Genesis of Gold Deposits. Rotterdam, A.A. Balkema, 11-30

Lindgren, W. 1895. Characteristic features of California gold-quartz veins. Geol. Soc. Am. Bull., 6: 221-240

Lines, K.J. 1998. "Changing our perceptions"-examining the geological challenges of the transition from selective underground mining to large-scale open-pitting of the Golden Mile, Kalgoorlie, Western Australia. In: G. Walton; J. Jambor (eds.) Pathways '98, Extended Abstract Volume, 123-125

Lobato, LM. 1998. Estilos e controles da alteração hidrotermal em depósitos lode-gold associados a $B I F s$ do Grupo Nova Lima do Quadrilátero Ferrífero, MG. In: SBG, Congr. Brás. Geol., 41, Belo Horizonte, Anais, in press

Lobato, L.M.; Silva, S.R.; Simões, E. 1998a. Alteração hidrotermal na BIF do Corpo Espírito Santo, Mina de Ouro de Raposos, Quadrilátero Ferrífero. In: SBG, Congr. Brás. Geol., 41, Belo Horizonte, Anais, in press

Lobato, L.M.; Vieira, F.W.R.; Ribeiro-Rodrigues, L.C.; Pereira, L.M.M.; Menezes, M. Junqueira, P.A.; Martins Pereira, S.L. 1998b. Styles of hydrothermal alteration and gold mineralisations associated with the Nova Lima Group of the Quadrilátero Ferrífero: Part I, description of selected gold deposits. Rev. Bras. Geociências, 28(3), in press

Marchetto, C.L.M. 1997. Petrographic Studies of the São Bento Mine. São Bento Mineração S. A., Company Report (Unpublished)

Marshak, S.; Alkmim, F.F.; Jordt Evangelista, H. 1992. Proterozoic crustal extension and the generation of dome-and-keel structure in an Archean granite-greenstone terrane. $\mathrm{Mm} / \mathrm{re}, 357:$ 491-493

Martins Pereira, S.L. 1995. Controles LJtoestruturais da Mineralização Aurifera no Distrito de Santa Bárbara, Quadrilátero Ferrifero, M.G. Mina São Bento Inst. de Geociências, Universidade Federal de Minas Gerais, Belo Horizonte, M. Sc. Thesis, $158 \mathrm{p}$.

McCuiag, T.C.; Kerrich, R. 1994. Lode gold deposits: alteration systematics. In: D.R. Lenz (ed.) Alteration and Alteration Processes Associated with Ore-Forming System . St. John's, Canada, Geol. Assoc. Canada, 339-379 (Short Course Notes 11)

Menezes, M. 1996. Evolução mineralógica das encaixantes da mineralização aurífera na Mina de Santana -Mariana - MG. In: SBG, Congr. Brás. Geol., 39. Salvador, Anais, 3: $320-322$

Menezes, M. 1999. Estudo dos Controles Estruturais e Geoquímicos da Mineralização Aurifera da Mina de Santana. Inst. de Geociências, Universidade de Brasília, Brasília, Ph. D. Thesis, In Preparation.

Meyer, C.; Hemley, J.J. 1967. Wall Rock alteration. In: H.L. Barnes (ed.) Geochemistry of Hydrothermal Ore Deposits. New York, Holt, Reinhart and Winston, Inc., 166-235

Mikucki, E.J.; Ridley, J.R. 1993. The hydrothermal fluid of Archean lode-gold deposits at different metamorphic grades: compositional constraints from ore and wallrock alteration assemblages. In: R. Kerrich (ed.) Western Australian Gold Deposits. Berlin, Germany, Springer-Verlag, 469-481 (Mineralium Deposita 28/6)
Passos, R.V. 199. caracterização da Geometria de Zonas de Alteração Hidrotermal - Estudo de Caso no Depósito de Brumal, QF, MG. Inst. de Geociências, Universidade Estadual de Campinas, M.Sc. Thesis, In Preparation.

Pereira, L.M.M. 1996. Estudo da Alteração Hidrotermal do Corpo SE-2, Nivel 5 da Mina de Ouro de Jucá Vieira, Quadrilátero Ferrífero, MG. Inst. de Geociências, Universidade Federal de Minas Gerais, Belo Horizonte, M. Sc. Thesis, 204 p.

Phillips, G.N.; Groves D.L; Martyn, J.E. 1984. An epigenetic origin for Archean banded iron-formation-hosted gold deposits. Econ. Geol., 79(1): 162-171

Phillips, G.N. 1985. Archean Gold Deposits of Australia. Ciclo de Palestras sobre Met alogenia do Ouro. IGC-UFMG, $43 \mathrm{p}$.

Phillips, G.N. 1991. Wallrock alteration and P-T environments of gold deposition. In: F. Robert, P.A. Sheahan; S.B. Green (eds.) Greenstone Gold and Crustal Evolution. St. John's, Newfoundland, Canada, Geol. Assoc. Canada, 98-99 (NUNA Conference Volume)

Phillips, G.N.; Powell, R. 1992. Gold Only Provinces and their Common Features. Canberra, James Cook University of North Queensland, 30 p. (Contributions of The Economic Geology Research Unit 43)

Phillips, G.N.; Powell, R. 1993. Link between gold provinces. Econ. Geol., 88(5): 1084-1098

Reed, M.H. 1997. Hydrothermal alteration and its relationship to ore fluid composition. In: H.L. Barnes (ed.) Geochemistry of Hydrothermal Ore Deposits. New York, John Wiley \& Sons, Inc., 303-365

Ribeiro, R.K. 1998. Mineralogia, geoquímica e Gênese das Ocorrências Auríferas no Flanco Norte do Anticlinal de Mariana, Quadrilátero Ferrífero: Uma Nova Tipologia de Minério Denominada Burge. Inst. de Geociências, Universidade de Brasília. M.Sc. Thesis, $115 \mathrm{p}$.

Ribeiro-Rodrigues, L.C.; Friedrich, G.; Oliveira, C.G. 1996a. Gold mineralization in Archean banded iron formations in Brazil. In: Internal. Geol. Congress, 30, Beijing, Abstracts Volume, 2: 756

Ribeiro-Rodrigues, L.C.; Friedrich, G.; Chemale Jr., F.; Oliveira, C.G.; Carmo, V.E.F.; Vieira, F.W.R. 1996b. Structural evolution of the Archean BIF-hosted Cuiabá Gold Mine area, Iron Quadrangle, Brazil: implications for the genesis and controls of the gold mineralization. 15. Geowissenschaftliches Lateinamerika-Kolloquium, Hamburg, Terra Nostra, 8: 117

Ribeiro-Rodrigues, L.C.; Friedrich, G.; Oliveira, C.G.; Vieira, F.W.; Biasi, E.F.; Callegari, L.A. 1996c. The BIF-hosted Cuiabá gold deposit, Iron Quadrangle, Minas Gerais, Brazil: characteristics, controls and genesis. In: SBG, Congr. Bras. Geol., 39, Salvador, Anais, 7: 224-228

Ribeiro-Rodrigues, L.C.; Friedrich, G.; Vieira, F.W.R.; Chemale Jr., F.; Oliveira, C.G. 1997. Structural styles of greenstone-hosted gold deposits in the Quadrilatero Ferrífero, Minas Gerais, Brazil. SBG, Simp. Nac. Est. Tectônicos (SNET), 6, Brasília, Extended Abstract Volume, 363-366

Ribeiro-Rodrigues, L.C. 1998. Gold in Archean Badend Iron-Formation of the Quadrilátero Ferrífero, Minas Gerais, Brazil - The Cuiabá Mine. Aachen University of Technology, Aachen, Germany, Aachener Geowissenschaftliche Beitrage, Band 27, Ph. D. Thesis, 264 p.

Ridley, J.R. 1990. Constraints from alteration assemblages on gold-bearing hydrothermal fluid composition and source. In: S.E. Ho; D.I. Groves; J.M. Bennet (eds.) Gold Deposits of the Archean Yilgarn Block, Western Australia: Nature, Genesis and Exploration Guides. Nedlands, University of Western Australia, 268-272

Robert, F.; Kelly, W.C. 1987. Ore-forming fluids in Archean gold-bearing quartz veins at the Sigma mine, Abitibi greenstone belt, Quebec, Canada: Econ. Geol., 82 1464-1482

Robert, F.; Sheahan, P.A. 1991. Oral reports by chairmen of working groups. In: F.Robert; P.A. Sheahan; S.B. Green (eds.) Greenstone Gold and Crustal Evolution. St. John's, Canada, Geol. Assoc. Canada, 100-110 (NUNA Conference Volume)

Robert, F; Sheahan, P.A.; Green S.B. (eds.) 1991. Greenstone Gold and Crustal Evolution. St. John's, Canada, Geol. Assoc. Canada, 252 p. (NUNA Conference Volume)

Roberts, R.G. 1988. Archean lode gold deposits. In: P.A. Sheahan; M.E. Cherry (eds.) Ore Deposit Models I. St. John's, Canada, Geol. Assoc. Canada, 1-199 (Geoscience Canada Reprint Series 3)

Romberger, S.B. 1986. The solution chemistry of gold applied to the origin of hydrotherma deposits. In: L.A. Clark (ed.) Gold in the Western Shield. Montreal, Canadian Inst. Mining Met all. 168-186 (Special Volume 38)

Rolim, S.B.A. 1999. Assinatura Geofísica dos Depósitos de Ouro da Porção Central do Quadrilátero Ferrífero. Inst. de Geociências, Universidade Estadual de Campinas, Ph.D. Thesis, In Preparation

Rose, A. W.; Burt, D.M. 1979. Hydrothermal alteration. In: H.L. Barnes (ed.) Geochemistry of Hydrothermal Ore Deposits. New York, John Wiley \& Sons, 173-235

Rubie, D.C. 1990. Mechanism of reaction-enhanced deformability in minerals and rocks. In: D.J. Barber; P.G. Meredith (eds.) Deformation Process in Minerals, Ceramics and Rocks. London, Unwin Hyman/Min. Soc. Great Britain and Ireland, 423 p.

Schrank, A.; Oliveira, F.R.; Toledo, C.L.B.; Abreu, F.R. 1996. The nature of hydrodynamic gold deposits related to Archean Rio das Velhas Greenstone Belt and overlying Paleoproterozoic Minas Basin. In: SBG, Symp. Archean Terranes of South American Platform, Brasilia, Extended Abstracts Volume, 60-61

Schrank, A.; Machado, N. 1996. Idades U-Pb em monazitas e zircões das minas de Morro Velho e Passagem de Mariana, Quadrilátero Ferrífero (MG). In: SBG, Cong. Bras. Geol., 39, Salvador, Anais, 6: 470-472

Shock, E.L.; Helgeson, H.C. 1988. Calculation of the thermodynamic and transport properties of aqueous species at high pressures and temperatures: correlation algorithms for ionic species and equation of state predictions to $5 \mathrm{~kb}$ and $1000^{\circ} \mathrm{C}$. Geochim. Cosmochim. Acta, 52: 2009-2036

Sibson, R.H. 1990a. Fault structure and mechanics in relation to greenstone gold deposits. In: F. Robert; P.A. Sheahan; S.B. Green (eds.) Greenstone Gold and Crustal Evolution. St. John's, Canada, Geol. Assoc. Canada, 54-60 (NUNA Conference Volume)

Sibson, R.H. 1990b. Faulting and fluid flow. In: B.E. Nesbitt (ed.) Fluids in Technically Active Regimes of the Continental Crust. Nepean, Canada, Min. Assoc. Canada, 92-132 (Short Course 18)

Skinner, B.J.; Barton, P.B. 1973. Genesis of Mineral Deposits. Annual Review of Earth Planetary Sci. Letters. 1: 183-211 
Skinner, B.J. 1997. Hydrothermal mineral deposits: what we do and don't know. In: H.L. Barnes (ed.) Geochemistry of Hvdrothermal Ore Deposits. New York, John Wiley \& Sons Inc., 1-29

Souza Filho, C.R. 1991. Met alogênese do Ouro em Zona de Cisalhamento. Área Tinguá, "Greenstone Belt" Rio das Velhas, MG. Inst. de Geociências, Universidade Estadual de Campinas, Campinas, M. Sc. Thesis, $254 \mathrm{p}$

Susak, N.J. 1994. Alteration factors affecting ore deposition. In: D.R. Lenz (ed.) Alteration and Alteration Processes Associated with Ore-Forming Systems. St. John's, Canada, Geol. Assoc. Canada, 115-130 (Short Course Notes 11)

Toledo, C.L.B. 1997. Controle Estrutural da Mineralização Aurífera na Mina de Cuiabá, Setor Noroeste do Greenstone Belt Rio das Velhas, Quadrilátero Ferrifero. Inst. de Geociências, Universidade Estadual de Campinas, Campinas. M. Sc. Thesis, 166 p.

Vial. D.S.; Ferreira Jr, M.G.; Ferrari, P.G. 1987. A lapa seca na mina de Morro Velho: metavulcanitos alterados hidrotermalmente. SBG, Simp. Geol. Minas Gerais, 4 Belo Horizonte, Anais, 7: 369-390

Vial, D.S. 1988. Mina de ouro da Passagem, Mariana, Minas Gerais. In: C. Schobbenhaus; C.E. Coelho, (eds.) Principais Depósitos Minerais do Brasil: Met als Básicos Não-Ferrosos, Ouro e Alumínio. Brasília, DNPM/CVRD. 3: 421-430

Vieira, F.W.R. 1986. Caracterização Petrográftca do Minério de Faina e Pontal. Mineração Morro Velho S.A., Company Report, 8 p. (Unpublished)

Vieira, F.W.R. 1987a. Novo contexto geológico para a mina de ouro de Raposos. In: SBG, Simp. Geol. Minas Gerais, 4, Belo Horizonte, Anais, 7: 343-357

Vieira, F.W.R. 1987b. Gênese das mineralizações auríferas da mina de Raposos. SBG, Simp. Geol. Minas Gerais, 4, Belo Horizonte, Anais, 358-368

Vieira, F.W.R.; Oliveira, G.A.I. 1988. Geologia do distrito aurífero de Nova Lima, Minas Gerais. In: C. Schobbenhaus; C. E. S. Coelho, (ed.) Principais Depósitos Minerais do Brasil. Met als Básicos não Ferrosos, Ouro e Alumínio, Brasília, DNPM-CVRD, 3: $377-391$

Vieira, F.W.R. 1988. Processos epigenéticos da formação dos depósitos auríferos e zonas de alteração hidrotermal do Grupo Nova Lima, Quadrilátero Ferrífero, Minas Gerais. In: SBG, Congr. Brás. Geol., 35, Belém, Anais, 1: 76-86
Vieira, F.W.R. 1991a. Textures and processes of hydrothermal alteration and mineralization in the Nova Lima Group, Minas Gerais, Brazil. In: E. A. Ladeira (ed.) Proceedings of Brazil GOLD'91, the Economics, Geology, Geochemistry and Groceedings of Brazil GOLD'91, the Economics, Geology, Geochemistry and

Vieira, F.W.R. 1991b. Petrologia e litogeoquímica do setor W do greenstone belt Rio das Velhas, MG. In: Grupo AMSA-Mineração Morro Velho, Simp. Int. Min. e Geol., 1, Nova Lima, Anais, 130-155

Vieira, F.W.R. 1991 c. Domínios Estruturais da Mina de Jucá Vieira. Mineração Morro Velho S.A., Company Report, 43 p. (Unpublished)

Vieira, F.W.R. 1992. Geologia da Mina de Cuiabá, Níveis 03 e 04. Mineração Morro Velho S.A., Company Report, 23 p. (Unpublished)

Vieira, F.W.R.; Simões, E. J. M. 1992. Geology of the Nova Lima area and excursion to the Raposos Mine. In: IUGS UNESCO, Gold Deposit Modeling Course, 1-24

Toledo, C.L.B.; Xavier, R.P.; Schrank, A.; Vieira, F.W.; La Rosa, M.T.; Silva, D. 1998. In: SBG, Congr. Bras. Geol., 41, Belo Horizonte, Anais, in press

Walton, G.; Jambor, J. (eds.) 1998. Pathways' 98, Extended Abstracts Volume, Vancouver, Canada. British Columbia \& Yukon Chamber of Mines/Society of Economic Geologists, 248 p.

William-Jones, A.E.; Wood, S.A.; Mountain, B.W.; Gammons, C.H. 1994. Experimental water-rock interaction: applications to ore-forming hydrothermal systems. In: D.R. Lenz (ed.) Alteration and Alteration Processes Associated with Ore-Forming Systems. St. John's, Canada, Geol. Assoc. Canada, 131-160 (Short Course Notes ID

Zucchetti, M. 1998. Geoquímica dos Metabasaltos do Grupo Nova Lima, Supergrupo Rio das Velhas, Quadrilátero Ferrifero, Minas Gerais. Inst. de Geociências, Universidade Federal de Minas Gerais, Belo Horizonte. M. Sc. Thesis, 124 p.

Manuscrito A-975 Manuscrito recebido em 15 de abril de 1998 Revisão dos autores em 30 de setembro 1998 Revisão aceita em 05 de outubro de 1998 